\title{
MALE PARODY, SKETCH COMEDY AND CULTURAL SUBVERSION: \\ THE WORK OF SCOTT THOMPSON, RICK MERCER AND STEVE SMITH
}

by

Danielle Deveau

B.A. University of Alberta, 2004

\author{
A thesis \\ presented to Ryerson University and York University \\ in partial fulfillment of the \\ requirements for the degree of \\ Master of Arts \\ in the Joint Programme of \\ Communication and Culture
}

Toronto, Ontario, Canada, 2006

(C) Danielle Deveau 2006 
Library and

Archives Canada

Published Heritage

Branch

395 Wellington Street

Ottawa ON K1A 0N4

Canada
Bibliothèque et

Archives Canada

Direction du

Patrimoine de l'édition

395 , rue Wellington

Ottawa ON K1A 0N4

Canada

Your file Votre référence

ISBN: 978-0-494-40793-6

Ourfile Notre référence

ISBN: 978-0-494-40793-6

NOTICE:

The author has granted a nonexclusive license allowing Library and Archives Canada to reproduce, publish, archive, preserve, conserve, communicate to the public by telecommunication or on the Internet, loan, distribute and sell theses worldwide, for commercial or noncommercial purposes, in microform, paper, electronic and/or any other formats.

The author retains copyright ownership and moral rights in this thesis. Neither the thesis nor substantial extracts from it may be printed or otherwise reproduced without the author's permission.
AVIS:

L'auteur a accordé une licence non exclusive permettant à la Bibliothèque et Archives Canada de reproduire, publier, archiver, sauvegarder, conserver, transmettre au public par télécommunication ou par l'Internet, prêter, distribuer et vendre des thèses partout dans le monde, à des fins commerciales ou autres, sur support microforme, papier, électronique et/ou autres formats.

L'auteur conserve la propriété du droit d'auteur et des droits moraux qui protège cette thèse. $\mathrm{Ni}$ la thèse ni des extraits substantiels de celle-ci ne doivent être imprimés ou autrement reproduits sans son autorisation.
In compliance with the Canadian

Privacy Act some supporting forms may have been removed from this thesis.

While these forms may be included in the document page count, their removal does not represent any loss of content from the thesis.
Conformément à la loi canadienne sur la protection de la vie privée, quelques formulaires secondaires ont été enlevés de cette thèse.

Bien que ces formulaires aient inclus dans la pagination, il n'y aura aucun contenu manquant.

\section{Canadä}




\section{BORROWER'S PAGE}

Ryerson University requires the signatures of all persons using or photocopying this thesis. Please sign below, and give address and date. 


\begin{abstract}
Male Parody, Sketch Comedy and Cultural Subversion:

The Work of Scott Thompson, Rick Mercer and Steve Smith

Master of Arts 2006

Danielle Deveau

Joint Graduate Programme in Communication and Culture

Ryerson University and York University

"Male Parody, Sketch Comedy and Cultural Subversion" is a Master's thesis that analyzes the male performances of Canadian comedians Scott Thompson, Rick Mercer and Steve Smith. Queer and feminist scholars suggest that subversive gender performance techniques such as camp can destabilize compulsory heteronormativity and binary gender constructions. Through the study of sketch comics Thompson, Mercer and Smith, it is evident that a range of masculine performances, both implicitly and explicitly in support of queer politics, are supported within popular comedy and Canadian mainstream media. The diverse comic techniques used by these actors prove effective in critiquing aspects of patriarchy, masculinity and heteronormativity as well as questioning essentialist assumptions behind social notions of hierarchy and marginality.
\end{abstract}




\section{ACKNOWLEDGEMENTS}

I would like to thank: Dr. Dennis Denisoff for his enthusiasm for this project and unbelievable dedication to seeing it fully realized; Dr. Jennifer Burwell and Dr. Steven Bailey for their valuable insight, guidance and accommodation; Dr. Ruth Panofsky and Dr. Caitlin Fisher for their encouragement and wise teachings; Peter Ryan and Katarina Kuruc for always helping out; Professor Bruce Elder and Dr. Fred Fletcher for debate lessons; and of course, my friends and family for their constant support. 


\section{CONTENTS}

AUTHOR'S DECLARATION

BORROWER'S PAGE

ABSTRACT iv

ACKNOWLEDGEMENTS $\quad \mathrm{v}$

INTRODUCTION Male Parody, Sketch Comedy and

Cultural Subversion 1

CHAPTER ONE Scott Thompson's Buddy and

The Radical Threat of Traditional Camp $\quad 19$

CHAPTER TWO Political Satire and the Disruption of

Masculinity in The Rick Mercer Report 38

CHAPTER THREE Steve Smith's Red Green and

Playing Possum with Masculinity 54

CONCLUSION Masculine Performance, Queer Politics

and the Erasure of Identity 71

$\begin{array}{ll}\text { ENDNOTES } & 76\end{array}$

$\begin{array}{ll}\text { WORKS CITED } & 79\end{array}$ 


\section{Introduction:}

\section{Male Parody, Sketch Comedy and Cultural Subversion}

In this thesis, I examine the ways in which male sketch comics on contemporary Canadian television have explored and critiqued dominant masculinity and heteronormativity through gender performance and parody. ${ }^{1}$ Using a critical framework that builds on recent theories of gender and parody, I discuss Scott Thompson's use of camp through his character Buddy Cole (The Kids in the Hall), Rick Mercer's satirical feminist representations of defeated patriarchs (The Rick Mercer Report), and Steve Smith's formation in The Red Green Show of what I argue is a unique example of heterosexual male camp. It is my contention that the diverse comic techniques used by these actors prove especially effective not only in critiquing aspects of patriarchy, masculinity and heteronormativity but also, more broadly, in problematizing essentialist assumptions behind social notions of hierarchy and marginality.

This project begins with an exploration of Thompson's portrayal of male femininity through camp. This is followed, in the second chapter, with a consideration of Mercer's use of a more bitingly satiric portrayal of incompetent, unstylish models of masculinity in order to challenge gender conventions similar to those addressed by Thompson. If, however, my analysis were limited to only these two comics, who are both gay, the subject under exploration could appear inaccurately to be circumscribed by 
issues of sexual orientation. Thompson does declare that his work is informed by his sexuality, and he has made a comic career out of being labelled "the gay one." His homosexuality is often foregrounded in his work and, in a 1993 interview with Maclean's, he expressed resentment about the AIDS movies of the 1980s that he felt misrepresented gay men: "those fags who looked straight, acted straight, were straight they're offensive. They don't exist." In contrast, Mercer has made it clear that, in his view, sexuality is not always a relevant component of his performance. According to Jonathon Gatehouse, when Mercer was recently outed by the Globe and Mail, he permitted it only reluctantly, and he continues to avoid presenting his personal life in press interviews.

This pairing of two gay comics does not only risk erasing the differences in their own approaches to their sexuality; it also suggests an essentialist conception of sexuality and gender that the theories I invoke actually work against. To say that the comic works of Thompson and Mercer are linked by the men's homosexuality is to imply the existence of an original gender over which they then mapped their performances. I argue, however, that all genders are equally performative and therefore extensively diverse and flexible. As Moe Meyer argues of camp, "peer beneath the surface and all you will find is another surface" (105). This study explores the possibility of perceiving the politics of parody as it can be interpreted by the viewer. Sensitivity to sexuality as existing within interpretive interactions between producers and consumers is especially important for my consideration of Steve Smith's character Red Green as an example of masculine parody. Like Thompson, Smith implements a sympathetic, comic critique of gender and yet, like 
Mercer's work, Smith's performance undermines essentialist assumptions regarding gender and sexuality without being explicitly linked to queer praxis.

Unlike notions of femininity and femaleness, which have undergone rapid change in the twentieth century due to subsequent waves of feminism, conceptions of maleness have remained relatively rigid within mainstream discourses until fairly recently. The narrow role available to men as the provider and master in the conventional nuclear family continues to be reflected in popular culture despite the fact that it often does not map onto the lived experiences of biological males. Likewise, the presentation of "the male" and "the female" as naturally complementary halves in a sexual binary does not adequately represent the complexities of sexuality that have long existed and are now, more than ever, being publicly recognized. It is increasingly acknowledged that physical attributes often seen as signs of particular sexes do not in fact accord with a male/female binary model; rather, humans display these attributes to varying degrees and in diverse combinations. Similarly, the notion that genders are simply social representations of biological sexes is rapidly having its limitations exposed. Just as sex is not biologically predetermined but formed predominantly through institutional discourses such as the scientific and medical, gender categories are not patterned on sexes but are performative formulations that are often mapped onto bodies in ways that do not reflect or engage with any innate physical characteristics.

While mainstream media representations of masculinity and male sexuality have remained relatively traditional, sketch comedy has been more successful in developing nuanced and transitory models of gender. Despite the frequently voiced claim among scholars that mainstream society tends to hold on to normalized views of gender and 
sexuality, sketch comedy reveals that the biases inherent to such essentialist models does not arise from the narrowness of the selection of gender identities but from the hierarchy with which the hegemony has imbued these identities. As a consideration of sketch comedy's frequent play with male identity demonstrates, Canadian mainstream society is well-prepared to recognize and appreciate a diverse range of gender types.

Within the Canadian media, comedy has served for decades as a vital form of cultural resistance for marginal groups by providing space for a mainstream dialogue on controversial and often overlooked issues. But why has sketch comedy been so successful when other forms of Canadian media production have not? One reason is that sketch comedy is relatively cheap to produce. Indeed, the cheap look and obvious impermanence of the set often serves as a valuable aspect of the comic production. In sketches that address the mundanity of traditional family life, for example, kitchens and living rooms are frequently presented in exaggerated and stereotypical designs. By cheaply and imperfectly reflecting the style of the middle-class nuclear family home, such material situates its audience in a familiar domestic context, but yet simultaneously signals the artificiality of the scenario. The consciously false façade does not invite the audience's suspension of disbelief, but rather encourages its recognition of parodic performance and comic commentary. Moreover, sketch comedy, unlike stand-up comedy, has visual and textual narratives for drawing in the audience. And unlike situation comedies, which do necessitate the suspension of disbelief and sustained viewer identification, sketch comedy has no such demand.

Sketch comedy is heavily dependent on cultural stereotypes and the exaggerated mimicry of famous individuals. Such exaggeration is a mainstay of both parody and 
irony, techniques that gained considerable scholarly attention during the 1980 s and 1990s, and remain popular to the present day. Parody is the exaggerated copy of an identity or text for comic effect with the primary aim of inducing laughter rather than making a moral point. ${ }^{2}$ Its emphasis on copying an apparent original makes it especially well suited to the topic of gender- and sex-based performativity. Meanwhile, selfdeprecating irony takes social stereotypes and clichés and turns them against both the perpetrators and victims of the stereotypes. This particular form of irony sustains what Linda Hutcheon calls a "double meaning" that both reinforces and undermines dominant culture $(1990,14)$. Such irony was often found in Canadian popular culture from the later half of the twentieth century, and is apparent, for example, in characters presented by Thompson, Mercer and Smith. Thompson's utilization of gay clichés, for instance, can be interpreted as both reinforcing and problematizing homophobic stereotypes. Likewise, Smith's character Red Green is often not explicitly acknowledged as the comic performance of a masculine identity, as opposed to a sincere representation of what some Canadians would recognize as a traditional, middle-class man.

Parody's mock performance of gender demands a temporary alleviation of the control of normative constructions, using artifice to disrupt the repetition that sustains an image of a permanent gender norm. It is through its ability to create these suspended moments that parody undermines the notion of an original sex or sexes. By ironizing familiar male identities (both masculine and feminine), Thompson, Mercer and Smith are neither mocking an original, nor paying it parodic homage. Rather they are leading their audiences to question the very notion of an original. The comics suggest the performative 
constitution of sex and gender through the ease with which they don these identities and sell them to mainstream viewers.

The fact that three comics can comfortably present disparate versions of masculinity and maleness to one mainstream Canadian audience undermines gender fixity in general. The sexual parody that these comics invoke is not only a means of mocking the masculine subject but, in some instances, alters mainstream perceptions of gender. According to Mark Simpson, gender imitation "can express a desire to revolt against that most tyrannical of laws, the "natural' link between sex and gender" (180). In separating gender from sex, Judith Butler concludes that, gender is a kind of action that can potentially proliferate beyond the binary limits imposed by the apparent binary of sex. Indeed, gender would be a kind of cultural/corporeal action that requires a new vocabulary that institutes and proliferates present participles of various kinds. (143)

When she goes on to ask "how would such a project become culturally conceivable?" (143), one can turn to Canadian sketch comics for an answer. They do not - and cannot be expected to - set the framework for a new process of gender signification, but they do successfully present an interrogation of gender hierarchies through a medium more popular than academic scholarship. They are thus closer to making alternative conceptions of masculinity and sexuality conceivable, if not initially realizable, by a broader spectrum of society. 


\section{Theoretical Framework}

In my theoretical analysis of gender parody, my emphasis is on conscious comedic parody as opposed to unconscious performativity. Nevertheless, as I demonstrate, it is this performativity that sketch comedy often brings forward, at the expense of notions of originary sex. According to Butler, "there is no gender identity behind the expressions of gender; ... identity is performatively constituted by the very 'expressions' that are said to be its results" (33). In this sense, the term "gender performance" is almost made redundant, as gender is always already performative, and to speak of someone's gender is to speak automatically of artifice. Therefore, to describe gender as parody is not to imply the existence of an original. The parody that occurs is of the very notion that a visible and essential sexuality exists and continues to be stylized through repetition.

Recognizing that gender and sex are constituted only through culture opens the traditional sex binary to criticism. Previously assumed by many to be an essential, foundational structure, the notion of sex has recently been more vigorously problematized, with more people now recognized as enacting genders that do not match any sort of biological sex. In fact, as Monique Wittig has argued, the distinctions of sex and gender can be said to serve no practical purpose but to divide society in such a way as to support compulsory heteronormativity's economic, political and social needs (2). As Butler notes,

When the constructed status of gender is theorized as radically independent of sex, gender itself becomes a free-floating artifice, with the consequence that man 
and masculine might just as easily signify a female body as a male one, and woman and feminine a male body as easily as a female one. (10) Constituting signifiers such as "man," "masculine," and "female" as free-floating and interchangeable allows for an array of genders and the severance of the popular conflation of "man" with "masculine" and "woman" with "feminine," as well as a disruption of the normative conception of the bodies they are assumed to map. This complication creates a space in which the lie that is the sex binary can be exposed. Male bodies and female bodies are not exclusive to one another. Nor are they the only bodies that exist. They are, however, often the only linguistically acknowledged bodies and this culturally signified reality is the root of the binary fabrication addressed by the sketch comics in my study.

As I will show, parodic performances within sketch comedy can help denaturalize dominant codes of sex and gender, a contribution to the permanent disruption of the false primacy of mainstream heteronormativity that has yet to be adequately addressed by scholars of gender identity formation. According to Chris Brickell, this rupture will be difficult to accomplish but, through countercultural action, it can gradually alter hegemonic discourses surrounding gender, sex and sexuality (40). Brickell argues for a subversive performance of masculinities that enables not only ironic repetition, but also the production of oppositional knowledges that maintain sustained challenges to dominant notions of gender (39). Critical of Butler's focus on ironic inversion and theoretical subversion, Brickell demands a stronger sociological acknowledgement of cultural structures (36). ${ }^{3}$ 
Scholarship that reflects a sociological sensitivity also tends to give greater emphasis to conscious parody as an act of social commentary. Robert Hanke, for example, has worked toward a sociological model akin to that suggested by Brickell. In his work, Hanke applies feminist theories of gender performance to the representation of masculinity in American situation comedies. These parodies of masculine identities are arguably part of a men's movement reaction to feminism, but they also implicitly destabilize hegemonic masculinity by mocking macho posturing as inadequate. Nevertheless, such representations of hyper-masculinity in situation comedies ultimately reinforce the ideologies of the nuclear family and heterosexual primacy. In short, such gender comedy proves capable of outlining and reinforcing particular sex role constructions. In contrast to the situation comedies of the early 1990 s which appeared to defend normative gender roles, the sketch comedies of Mercer and Smith are successful in their deconstruction of these rigid roles.

Among the recognized forms of gender parody, camp is perhaps the most blatant challenge to common gender assumptions. According to Chuck Kleinhans, "camp is an ironic and parodic appreciation of an extravagant form that is out of proportion to its content, especially when that content is banal or trivial" (186). This definition of camp is so vague as to cover potentially not only Thompson's style of male femininity but even Smith's stylized masculinity. There are, however, historical claims and popular expectations of this trope that must be taken into consideration. Most notably, camp is historically linked to what has been described - in dangerously essentialist terms - as a gay sensibility. Somewhat more broadly, Moe Meyer posits that "camp refers to strategies and tactics of queer parody" (9). According to Meyer, camp must be defined 
according to queer political agency and performance such that, when camp ceases to embody a "specifically queer cultural critique," it ceases to be camp per se, becoming instead an "appropriation of queer praxis" (1). In his queer male sketches, Thompson himself explores this conception of camp as an imitation devoid of origin. In conflict with Meyer's demands, however, both Mercer and Smith carry the notion of camp as imitation without origin beyond the realm of queer sexual identity to portrayals of male identity that are among the most unlikely to be recognized as queer. They do so, however, for ends in concord with queer politics.

\section{Literature Review}

In $A$ Theory of Parody, Linda Hutcheon presents the parodic method as that most relevant to the postmodern cultural production of the late-twentieth century. Speaking specifically of Canadian production, she argues in Double Talking that irony as well has become "a more positive mode of artistic expression with renewed power as an engaged critical force" (13). She demonstrates the way in which, for example, feminist authors used parody to infuse theories and alternative ideological viewpoints into the mainstream. Hutcheon's works on parody address trends occurring in the late 1980s and early 1990s, when Thompson and Smith were developing and presenting their male parodies on sketch television. Although Mercer's work did not become popular until the mid-1990s, his comic consciousness can be seen to have developed out of this age of parody politics. Hutcheon does not acknowledge the political potential of parody within popular culture. Because parodic sketches are aimed at a populist audience, however, they have an as strong if not stronger potential to be taken up by the mainstream subconscious. As 
Nicole Matthews argues, in Comic Politics, popular parodic comedies often function to invert official culture and hegemonic power (14). Matthews criticizes theorists such as Pierre Bourdieu for underestimating the intelligence of "average" people. She instead supports David Cardiff's argument that the popularity of parodies such as Monty Python's Flying Circus is due to the particular history of the post-Second-World-War education of the British lower-middle class (36-37). The peculiar intellectual capital of these citizens enabled them to engage with the parody. The consumers of middle-brow parodies such as Monty Python were, Matthews notes, active in their consumption of the text, rather than passive, mindless and easily manipulated (47). Thus the success of parodies aimed at the British middle class was inescapably related to the activity of the audience and its ability to take up the political dialogues that these productions enacted. In their work on television consumption, John Fiske and John Hartley similarly argue that audience members are constantly reading and decoding the television message, as well as negotiating their stance towards its ideological framework (19). Fiske's article "Popular Television and Commercial Culture: Beyond Political Economy" is a response to critiques of his depiction of popular culture as both politically relevant and socially telling. According to Fiske, almost all popular culture is profit making, while high-brow culture is subsidized. This scenario reflects an elitism that opposes the study and appreciation of popular culture because of its close reliance on the market (22). Notably, Canadian popular culture has a history of subsidization, being carried primarily by a subsidized communications infrastructure. In Canada, there is an urge to create and protect a commercial culture of our own in order to diminish the extent to which we must draw upon that produced in the United States. When government policy is implemented 
to protect Canadian culture with content regulations, its focus is not only on literature, but also rock music, history and televised comedy. Thus, the Canadian context demonstrates that Fiske's distinction between high, supported culture and low, self-funded culture may be valid, but it is based on an artificial hierarchy privileging the art forms associated with those in power. Not surprisingly, sexually marginalized communities such as those defined as gay or queer turned to similarly de-valued venues of popular culture such as camp.

Theorizations of the constructionist character of sexual identity formation can be traced back to scholars such as Simone de Beauvoir. In her conceptualization of gender, Beauvoir finds that, while we are socialized to take on culturally sanctioned representations of our biological sex, we can, and occasionally do, choose to enact nonnormative gender constructions. Current mainstream conceptions of gender conceive of it as the signification of a biologically constituted sex. Beauvoir argues, however, that gender is not an automatic or natural continuation of sexed bodies, but something that we become. For Luce Irigaray, gender is even less fixed. It is a shifting and contextual phenomenon, a convergence of historic and cultural relations, but not the denotation of any substantive state of being. Meanwhile, Monique Wittig points to the category of sex itself as formulated as a link to the reproduction of compulsory heterosexuality. She calls, therefore, for a "post-genital politics" in which sex and gender norms, and therefore heteronormativity, would be erased.

Butler builds on these earlier theorizations to propose a broader concept of performance and its potential for subversions. "If gender attributes and acts, the various ways in which a body shows or produces its cultural signification, are performative," she 
posits, "then there is no pre-existing identity by which an act or attribute might be measured; there would be no true or false, real or distorted acts of gender, and the postulation of a true gender identity would be revealed as a regulatory fiction" (180). For Butler, gender is developed as if it were reality, with its sustained performance gradually concealing that it is a performance at all. This subterfuge then allows such "restricting frames of masculinist domination and compulsory heterosexuality" to persevere unchallenged. Beauvoir, Irigaray, Wittig, and Butler all suggest that the political goal, then, is to draw attention to the agenda hidden behind traditional sex and gender formations that normalize the regime of compulsory heterosexuality. Camp is seen by many as having the potential to accomplish this.

In his introduction to The Politics and Poetics of Camp, Moe Meyer proposes that camp's three main tenets are to be overtly political, to posit a queer discourse, and to embody a cultural critique that is queer in origin (1). But if we accept that all genders are performed, as Meyer appears to do, then the line between political enactment and performativity becomes difficult to demarcate. Notably, Meyer's articulation of camp as a queer politics - much like Jack Babuscio's - allows for the potential separation of heterosexuality from heteronormativity, such that a queer consciousness can be incorporated into heterosexuality. Despite the sustained correlation of camp action and queer politics throughout his argument, Meyer defines camp rather broadly as "the total body of performative practices and strategies used to enact a queer identity, with enactment defined as the production of social visibility" (5). Queer performative practices include masculine performance and, therefore, Meyer's definition of camp extends 
beyond gender exaggeration for gay and queer political purposes to encompass parodic gender resignification in general.

Scholarly research involving the establishment of historical examples of camp has maintained political intent as a necessary requirement. Thomas A. King, for example, argues that camp's early-modern beginnings "may have been well-informed political practices deploying the surfaces of the body oppositionally against ... controlling the subject through his or her interiority" (24). Similarly, both Gregory W. Bredbeck's "Narcissus in the Wilde" and Meyer's own "Under the Sign of Wilde: An Archaeology of Posing" present Oscar Wilde as using camp as a political technique (Bredbeck 51; Meyer; 102-103). Dennis Denisoff also argues that nineteenth-century parody's reliance upon double meanings raises issues around the notion of an original and provides the potential for resignification of dominant codes. He argues that "one particular aim for which parody has proven to be especially well suited is the undermining of normative idealizations by oppressed groups and individuals trying to negotiate their own positions within society" (4). Although applicable within the historical context of camp's emergence with the aesthetes, this argument is also particularly relevant to more recent conceptions of parody, especially given that, as Hutcheon notes, as early as the 1980s the parodic form began to dominate cultural production.

Masculine parody has been analyzed by both feminist and queer theorists. In Drag! Male and Female Impersonators of Stage, Screen and Television, F. Michael Moore studies the mainstream cultural representation of gender performance. Rather than focus on camp or drag queens, Moore analyzes the historical role of drag within high cultural forms such as Shakespearean theatre and classical ballet. He also acknowledges 
the popularity of female portrayals of masculine characters in the first half of the twentieth century. For Moore, "drag performances convey important truths about perception, gender roles, and sexuality" and this is the reason for drag's continuing popularity. In the introduction to Constructing Masculinity, Maurice Berger, Brian Wallis and Simon Watson call for an analysis of how masculinities are formed, fixed in place, and consequently performed (3). While they argue that masculinity cannot be universally defined, they also note that, "within the ideological structure of patriarchal culture, heterosexual masculinity has traditionally been structured as the normative gender" (2). As they suggest, masculinity, when performed by heterosexual men, is perceived as natural. The essays collected in Constructing Masculinity, however, do not focus on the performance of masculinity but on subversive male performance; the collection thus emphasizes a link between deviance and performance, inadvertently reinforcing the traditional sexual binary and the falsely naturalized link between normative males and masculinity.

Judith Halberstam makes this issue a key focus of her study Female Masculinity, arguing that "masculinity must not and cannot and should not reduce down to the male body and its effects" (1). While justifiably critical of masculinities theorized in relation to maleness, Halberstam over-extends her claim when she argues that only upon leaving the white, male, middle-class body can masculinity be perceived as political performance $(2$, 14). As the sketch comedy that I study demonstrates, even the narrow subset of the white, middle-class male body contains space for dissidence. As both Mercer and Smith reveal, the sketch performance of normative masculinity even by seemingly normative males can 
undermine the ideologies of patriarchy and male dominance, and perhaps even do so with greater nuance and mainstream influence.

Many analyses of men's performances of masculinity deal with a sexualized ideal. Mark Simpson argues, for example, in his study Male Impersonators, that the links between heterosexuality and homoeroticism are increasingly being blurred in popular culture. According to Simpson, in the mid-1990s, advertising embraced the sexualization and objectification of the male body such that gay men, "long considered somehow 'inauthentic,' succeeded, by their visibility, in bringing into question the whole category of masculinity, 'queering' the image of what should be the very archetype of allAmerican virility" (5). The contemporary "crisis" of masculinity is, in this context, in part a product of the denaturalization, homoeroticism and queer gaze supported by recent Hollywood culture. 


\section{Outline of Chapters}

The first chapter of this thesis, "Scott Thompson, Buddy Cole and the Radical Threat of Traditional Camp," analyzes Thompson's work during the early 1990s with the comedy troop The Kids in the Hall. As I demonstrate, Thompson uses camp to undermine traditional notions of maleness and to question normative sexuality. This is achieved through regular monologues which engage with camp history, as well as contemporary race and gender issues. Thompson's work is particularly notable because it presents camp performance through a popular medium at a time when gay characters were not regularly featured on network television.

Shifting the exploration of gender parody into the less familiar scholarly terrain of heteronormative male identity performance, the next chapter of my study situates popular Canadian satirist Rick Mercer within theories of masculine performance and feminist criticisms of the nuclear family. As I argue, constructionist theories of gender imitation allow Mercer's presentation of masculinity to be understood as a populist contribution to queer gender politics. Through satire, Mercer presents an affirmation of feminist positions regarding the institutions of the heteronormative family model and compulsory heterosexuality. At the same time, his work undermines the governmental and media structures that narrowly define and control sex and gender roles.

In my final chapter, I argue that not all gender performance must be explicitly and consciously political in order to support an analysis of parody as politicizing. "Steve Smith's Red Green and Playing Possum with Masculinity" is an analysis of the hypermasculine, stereotypically Canadian production The Red Green Show. On the surface, Smith's character appears to embody and celebrate the normative Canadian masculinity 
that Thompson's and Mercer's works challenge. Despite presenting a male figure that is not as readily recognized as a critique, Smith nevertheless succeeds in questioning traditional gender configurations. As I demonstrate, there is actually nothing normal about the character Red Green. Even his masculine sartorial paraphernalia (from plaid shirt to diverse tools) prove to be as parodic of the traditional white, middle-class male identity as Thompson's martini and lip-stick or Mercer's suit and microphone.

Through a comparison of three distinct male sketch comics, my thesis demonstrates that gender parody and non-binary conceptions of sexuality are supported not simply within some forms of comedy, but within mainstream Canadian culture and its broader project of tolerance and understanding. Nostalgia for tradition still exists within the nation's make-up. But as my work demonstrates, Canadians' willingness to entertain and be entertained by these comic challenges to normative masculinity reflects not only a growing tolerance of queer perspectives, but also a recognition that some longestablished institutions can benefit from some re-tooling. 


\section{Chapter One:}

\section{Scott Thompson's Buddy and the Radical Threat of Traditional Camp}

Popular comedy has generally always come across as rather innocuous. It therefore provides a less confrontational means through which one can work alternative discourses into a society that is not especially receptive to the politics and values associated with queer identities and what are often regarded as dissident sexualities. Over the course of his career and his many professional partnerships and collaborations, Scott Thompson has developed characters that parody and satirize mainstream North American notions of homosexuality. His career itself can be interpreted as steeped in irony. He has been marginalized not only as a Canadian cultural producer in a market saturated by American cultural goods, but also as a gay man who worked to achieve success in the years prior to the novelty of gay content on network television. He has grown to be a desirable commodity as both a Canadian comic and as a gay man that, as Fred Fejes argues, addresses a niche market based on the relative affluence of gay men and the growing consumption of "gay" cultural products by middle- and upper-class Americans (198).

Thompson has often chosen to portray gay characters in a stereotypical fashion. He has, not surprisingly, also heard criticism that such traditionally negative images of homosexuals play into conservative social norms while commoditizing gay and lesbian 
lifestyles. As I demonstrate in this chapter, however, Thompson's "Buddy" monologues effectively reveal that traditional gender parody techniques such as camp are still effective for asserting marginalized voices and undermining the power hierarchies that continue to dominate the political landscape in both Canada and the United States.

\section{Mainstreaming Gay Content and Viewership}

By the mid-1990s, gay and lesbian characters were no longer missing from network television shows. In fact, it became increasingly trendy to include gay characters, as well as episodes dedicated to what were seen as gay issues. In his study of gay representation on television in the United States, Ron Becker notes that networks began narrowcasting their audiences in order to better sell them to advertisers such that, by the mid-1990s,

the quality demographic that has become the most widely sought after isn't simply upscale adults but, more specifically, "hip," "sophisticated," urbanminded, white, college-educated, upscale eighteen to forty-nine year olds with liberal attitudes, disposable income, and a distinctively edgy and ironic sensibility. (391)

This audience not only includes gays and lesbians, but heterosexuals who consider themselves sympathetic to gay and lesbian issues. ${ }^{4}$ Consciously using gay material to increase ratings, networks and advertisers operated on the belief that the gay community had a great deal of disposable income (396). This view ignored many economically disenfranchised homosexual communities, such as lesbians and gay men of colour. It also ignored the overwhelming sexual oppression that most gays and lesbians faced daily 
within mainstream society. The notion that members of the gay community could be characterized as affluent, quality audience members and desirable consumers developed alongside and in tension with the gay civil rights movement. This community was thus both exploited as the consumers of stereotypical media images and strengthened by their new-found visibility on mainstream television. Representation on network television led to a greatly exaggerated characterization of gay economic power. As Becker notes, however, the audience in gay and lesbian politics can still act as "a collection of political constituents that can be mobilized" (390). In other words, an audience is capable of forming a community by linking displaced subjects through a common identity image, even if that image is inaccurate.

Television depictions of gays and lesbians have often been critiqued as stereotypical and commoditizing, and as reinforcing the image of heterosexuality as primary. Self-consciously positioning himself as gay, Thompson was complicit not only in the commoditization of gay identity, but also in the representation of an otherwise predominantly invisible community. Over the last two decades in Canada, the creativity and political self-consciousness required to formulate this critical parody has seen growing cultural support. The ironic Canadian disposition, for example, has grown out of a tradition of multiculturalism that maintains that to take one's own identity too seriously would be to privilege it in a way that diminishes and insults the identities of others. This disposition can be attributed, to an extent, to our proximity to the United States. The sharing of a border with this economic and political superpower has encouraged Canadian popular culture to internalize a feeling of inadequacy and paranoia arising from a sense of being under constant threat. Canada has itself of course not perfected 
pluralism, multiculturalism, or full sensitivity to homogenizing tendencies. It is the tensions that rise out of the inadequacies in our efforts to maintain thorough cultural tolerance that have in fact become the basis for much of our parodic and ironic selfevaluations, including those found in Thompson's camp sketches.

Camp is a form of parody that implements comic performance in the deflection of marginality and intolerance. It has been of particular value to the gay community in circumventing threats of violence. It is politicized by both its conscious performance of gender and its intentional stimulation of a dramatic response from others. As Jack Babuscio notes, "camp is an assertion of one's self-integrity - a temporary means of accommodation with society in which art becomes, at one and the same time, an intense mode of individualism and a form of spirited protest" (21). Camp has therefore been historically associated with personal and political liberation from the normative gender notions and sexual practices supported by the hegemony. Babuscio argues that "camp, by focusing on the outward appearances of role, implies that roles, and, in particular, sex roles, are superficial - a matter of style. Indeed, life itself is role and theatre, appearance, and impersonation" (24). Successful comedic parody does not attempt to mock lived experience through the exaggerated representation of an implied reality, but rather draws attention to the impersonations and artifice that generally pass as real in our daily lives.

While perhaps most obviously applicable to Thompson's well-known character of Buddy Cole, theories of camp and the politicization of performance are also relevant to discussions of many other sketches presented by the troop. The female characters portrayed by the Kids in the Hall, for example, were presented by men in drag. The gender construction is especially interesting, however, because the representations often 
appear to be intended to reflect the mediocrity or even physical inadequacies of the average woman, rather than the more readily camp style, excess, and exaggeration of drag queen performance. The group performed female gender much as white middleclass women ordinarily perform it and it is those moments of virtual verisimilitude that are often most comic. It is also those moments that most effectively destabilize essentialist assumptions by leading viewers to recognize that all of these men can readily take on a gender that does not map onto their bodies as biologically determined. The lack of exaggeration and gay politics in these sketches counters a description of them as camp, but the performances overlap with camp in their use of gender performance as a comic means of political commentary.

Such gender parody was a mainstay of the Kids in the Hall television show, which was produced by Lorne Michaels and the CBC starting in 1989. Immediately successful and quickly attaining a cult-like fan base, the show was picked up by HBO in 1990 and the comedy troop embarked on a cross-America tour. The following year was equally successful, leading Maclean's magazine to declare in 1993 that Thompson had become "the only openly gay man on North American network TV" (26). By the mid-nineties, his position as the lone gay voice ended with gay-themed television becoming a major programming trend. Nevertheless, in 1993, Thompson was more than content to be perceived as the token voice of gay identity; as he told Maclean's, "I wanted to have a career where people look at me and know I'm gay. I can build comedy on that. I want them to know, that's the fag" (1993). Thus, throughout the successful years of The Kids in the Hall when queer culture and scholarship was working against stereotypes of gay 
and lesbian identity, Thompson was often intentionally positioning himself as stereotypically gay.

The efficacy of the character of Buddy Cole and his relationship with his audience are more relevant after the "gay nineties" than even Thompson himself could have expected. One cannot help but be somewhat surprised that Buddy, a character whose main purpose was to confront audiences with a highly theatrical version of homosexuality, gained such quick and relatively unproblematic popularity. The monologues of this cigarette smoking, martini drinking fellow with a lisp were reservoirs of politicized parody and irony, specifically as they related to the gay male community. Buddy's sketches often drew upon current theoretical concerns and political events, and brought complex issues regarding gender and sexuality to a mainstream audience. Camp's stylistic excess, aestheticism, and comic elements create a space in which audiences are more willing to detach themselves from the implicit political commentary of the camp text. Only upon walking away from a performance do the audience members begin to consider more fully the social critiques that have worked their way into their psyches. $^{5}$

Notably, the theatricality and excess characteristic of camp are also a strong part of the sketch comedy tradition itself. This is perhaps in part why Thompson had the confidence to present an unapologetically stereotypical and arrogant camp character. Some who define camp as a technique for political resistance might not see Buddy's actions and statements as representative of queer activism. For example, his popular statement, "I may have only been born yesterday, but I still went shopping" (Pilot Episode) can be seen as politically regressive, especially in light of the growing tendency 
over the past two decades to assume that all gays and lesbians have a large degree of disposable income. Buddy's mantra is distinctly not akin to that enacted by Queer Nation, with their slogan "We're here, we're queer, we're not going shopping." While some activists would find his comic enactments lacking in immediate praxis, the Buddy monologues did take on major political issues not only by refusing to deny the history of gay identity formation (with all its clichés), but also by altering the content criteria of network television itself.

\section{Buddy Cole and the Oppressive Stereotype as Comic Tactic}

Buddy Cole was introduced to the television audience in The Kids in the Hall pilot episode and he instantly became a hit character. A half-French, half-English homosexual living in Toronto, Buddy was famed for knowing everyone and having an opinion about everything. Thompson used this character to push the boundaries of taste and decency on issues pertaining to not only gender and sexuality, but also race, class and cultural imperialism. In "Buddy's Island" (Episode 15), for example, Buddy does the unthinkable; he takes on Oscar Wilde. In his analysis of sexual parody, Denisoff notes that, "in aesthetic debates arising after the turn of the century, artists, authors, and critics were frequently concerned with negotiating their relations to their predecessors" (121). Thompson addresses this issue with his incorporation of Wilde (performed by David Foley) into this sketch, with Buddy then negotiating for queer cultural turf by ridiculing his hero. Stranded on a desert island with a choice of only one companion, our hero selects "The Great Aesthete." Expecting to be entertained, he asks Wilde for a charming quip and the late-Victorian responds with the well-known claim that, on his deathbed, he 
declared, "either that wallpaper goes or I do!" Buddy fakes a heartfelt laugh over this tired bon mot, but continues to give his predecessor attention and admiration. He carries on the conversation by inquiring whether Wilde is bothered at all by being dead. With his second attempt at charm, the author proclaims, "all in all, I'd rather be in Philadelphia." Buddy admits this is funny, but also points out that it was first said by W.C. Fields. Upon his third attempt to prove his great wit, Wilde declares, "I may have been born yesterday, but I still went shopping!" This proves too much for our Buddy, who evidently does not take kindly to having his own work plagiarized. He tells Wilde that the latter would never have lasted on television, adding: "do something with that hair, it's threatening to become more interesting than you." This interaction between the supposed original - Wilde - and the supposed later copy - the cliché that is Buddy - problematizes the very notion of originality, with Wilde being shown stealing material from a character from the future. It is in part this copying and the use it makes of familiarity and stereotype that enables a mainstream audience to accept Buddy.

In the sketch, Buddy, a model, sits on a stool in the centre of the set posing for Wilde, who struggles to impress the audience with his wit. He of course fails, in the end presenting no more than a parody of genius, thus undermining any actual notion of ingenuity. In the sketch, Thompson inverts the usual power hierarchy in which the artist uses his gaze to subordinate the model by presenting himself - the object of the gaze - as both objectified and in control. That is, Buddy takes up the model position upon the stool, but his management of Wilde also serves to remind the audience that they are on "Buddy's Island." Moreover, in this exchange, he complicates the usual valuing of dominant characteristics such as masculinity as superior to others. Rather than abandon 
the role of object in order to obtain authority, Cole constructs his feminine position as authoritative.

In presenting Wilde as plagiarizing Buddy, Thompson implies illogically that his own character is a precursor of one that came before it in history. This suggestion is itself called into question, however, by the fact that Buddy self-defines through his performance of camp, a technique that actually emphasizes the fallacy of any form of originality and authenticity. Thompson effectively reinforces this lack of originality at the end of the sketch when Buddy himself plagiarizes Wilde. When asked if he had anything to declare at a border crossing, the queer Canadian claims to have responded "only my genius." Wilde protests at having his own line used, but Buddy simply retorts, "So what? You owe me!" And so Buddy carries on Wilde's own plagiarizing labours. He is a contemporary, popular enactment of a form that Wilde promoted a century earlier. While paying homage to Wilde, Thompson simultaneously explores new camp possibilities offered by the medium of television. Buddy may suggest that he is the original in this new medium, but Thompson is sufficiently self-aware in his portrayal of the character to establish that such originality is not possible. Within queer politics, all notions of originality must be questioned, including those of homosexual essentialism. ${ }^{6}$

Thompson's ironic approach to essentialism is carried throughout his work, with him using camp and gay identities to evaluate non-gendered and non-sexual forms of marginalization as well. In "Buddy is Canadian" (Episode 20), for example, Thompson explores the tensions that are faced by the gay community in show business, only to discover that the one thing less appealing to agents and audiences alike than an actor being gay is his being Canadian. Buddy opens his monologue, cigarette and martini at 
hand, dramatically exclaiming that, "Show business is full! Of actors, singers, dancers and models. And then there's me: actor, singer, dancer, model . . Canadian." Buddy presents his experience as a gay Canadian in show business as a double-marginality, one that his agent attempts to avoid by awkwardly stifling it in pseudonyms. As Buddy explains:

When I'm overseas and people mistake me for American, I'm as outraged as when I'm mistaken for straight! No one wants to know that I'm gay, and even less people want to know that I'm Canadian. On my resume my agent replaced the word gay with blond and Canadian with outdoorsy. So...I replaced outdoorsy with blousy, which makes me a blousy blond.

Buddy sees these two marginalities as arguably equal, but he complicates the manner in which they interact. His flamboyant use of a small Canadian flag handkerchief into which he blows his nose both mocks stereotypes of homosexuality and questions intense nationalism. At the same time, however, his piece intertwines Canadianism and homosexuality. On the one hand, his derogatory parody of Canadian pride echoes the parody of gay pride. On the other, Thompson implicitly encourages Canadian audience members to transpose the marginality that they feel as Canadians within the North American context onto the marginality that homosexuals feel within a heteronormative culture. Thus, through the character of a nationalistic Buddy, Thompson encourages Canadians in general to empathize with homosexuals.

Nor do the comparisons end there. In the final line of his monologue, Buddy claims that Anne Murray exclaimed to James Baldwin over a cocktail, "it must be hard enough being black and gay; imagine if you were also Canadian, eh?" By foregrounding 
the double bind of gay and black identity, Thompson reveals a nuanced understanding of identity intersections. As this sketch suggests, no one marginalization can explicitly and unproblematically be seen as overshadowing another. And yet, Thompson posits the possibility that being Canadian is the ultimate marginality. In fact, the sketch, although stereotypically associated with asserting gay identity, makes Canadian marginality its focus. The monologue's opening statement does not even mention the character's gayness. That Buddy is gay can be inferred from the physical parody and an awareness of past monologues, but his Canadianness is apparently so marginal that it must be stated and restated. When it is erased as the more palpable "outdoorsy," a less marginal gay identifier "blousy" takes its place. The agent considers "Canadian" to signify an athletic interest in nature, an explanation that clearly does not map onto Buddy. The stacking of marginalities - black, gay, Canadian - becomes comic because it demonstrates that such categories of social oppression are too complicated to be either measurable or directly comparable.

Thompson frequently inverts the experiences of marginality to emphasize the inadequacy of such comparisons. For example, his argument that, in North American society, being Canadian is more difficult than being either black or gay demonstrates the misguided nature of any attempt to categorize and rank identities. The sketch "Buddy's Better" (Episode 2) delves even further into current gay and race politics with a consideration of the 1989 work of Dr. Jean-Phillipe Rushton, who claimed to have found a scientific correlation between sexuality, brain size, intelligence and race. By playing racism and homophobia off of one another, Thompson develops an intriguing analysis of white, heterosexual privilege rooted in recent understandings of pluralism and the politics 
of diversity. Buddy's monologue begins with a summary of the stereotypical appraisal of racial intellect: blacks are found to be inferior due to their strong sexual drive and love of dancing, while Asians are described as superior because of their mathematical acuity, tendency towards having smaller families, and weaker sex drives. Summing up this assessment, Buddy adds, "I guess that's why there's only a billion people in China; I mean, I'm certainly not having any children, yet I don't hear a lot of people running around touting the superiority of faggots." Having established the lack of logic behind these stereotypes, Cole then turns to Rushton's scientific evaluation of whites as superior: "They say that whites are smarter than blacks, but dumber than Orientals. I guess we're just right. We're the porridge that goldilocks chose." This interrogation of Rushton's work demonstrates that a supposedly objective science is not equally applicable to all racial groups. Buddy's comic promotion of white people highlights an academic and scientific tendency to normalize whiteness. The simplicity of this position is made apparent by the fact that Buddy, a campy homosexual, finds himself declaring throughout the piece that he is "just right" because of his race. At the same time, however, he notes that he shares the Chinese trait of having few children and the black traits of dancing and loving sex.

In "Buddy's Better," the character notes that heterosexuals are considered better than homosexuals because gays tend toward deviant sexuality and promiscuity, to which Cole responds "I guess that means we're also black." Comic conflations across categorizing systems effectively bring forward the fact that stereotypes develop more out of convenience than out of lived experience. Buddy most effectively brings the issue home when he demonstrates some of the ways in which marginal groups appear to share 
negative defining characteristics. This is the claim, for example in the conflation of gays and Orientals as both preferring small families, or of gay and black men as both hypersexual. This juxtaposing strategy reaches its comic peak, in Thompson's sketch, when he considers the role of language itself in identity formation. "They say that every different group has their own language," Buddy notes, "For example: Fags say things like 'girl' and 'sister' and 'what's her problem.' Another example... foxy black mamas, they say things like 'girl' and 'sister' and 'what's her problem.' Makes you think." Here, Thompson references the stereotyping of language as a problematic and inaccurate marker for identity categories when he finds that gay men and "foxy black mamas" apparently have the same oral codes. This juxtaposition of distinct cultural groups, as well as the assessment of their similarities, draws attention to the illogical methods through which hegemonic discourse itself categorizes citizens.

The sketch "Buddy's Better" does not only offer a general comedic evaluation of stereotyping. Thompson also uses the piece to address the particular lived consequences of systemic racism and inequality. At one point, Buddy comments that blacks are inferior because they supposedly commit more crime and test lower on white people's I.Q. tests. Hmm, I don't know about you but, if I was raised in the ghetto, I'd be out there ripping off whitey and forgetting the capital of Maine. And Orientals aren't supposed to be as sexually driven as blacks or whites. Hmmm, I guess all those tourists who flock to the fleshpots of Bangkok are there for the food.

In this monologue, Thompson presents oppression as a consequence of the institutionalization of inequality. He distinguishes, for example, between an educated 
white population that defines knowledge and a ghettoized black population that is expected to conform to this definition. He also differentiates between affluent Western tourists and the sexualized youth of the impoverished East and South. While the character of Buddy is solidly grounded in the gay camp tradition, Thompson makes use of camp to draw attention to various other performed stereotypes such as the false construction of Asians as promiscuous in order to exonerate Westerners of their sexual abuses.

The issues that Thompson addresses are often most familiarly situated within academic debates steeped in queer and race theory. Thompson, however, effectively packages these problems for a mainstream audience that is in fact largely white, heterosexual, and American. Notably, he often does so to challenge the values of this very demographic, deflating Rushton's celebration of white superiority through Rushton's own logic. After using the scientist's claims to conclude that white people are "just smart enough," for example, Buddy finds that he must modify this insight, acknowledging that whites are apparently "smart enough to stay out of trouble, but too dumb to run convenience stores." The claims of science are found to be incongruous with the roles mapped out for marginalized groups in society. Moreover, the diversity of the human experience and the global migration of citizens both complicate notions of universality, with even highly localized communities not actually sharing essential characteristics. Asian immigrants to North America, for example, while considered intellectually superior, are nevertheless ghettoized into low-paying service industry jobs. As Thompson suggests, marginal groups are permitted to take on the positive characteristics of dominant society when systemically convenient, but are often denied these characteristics through oppressive stereotyping. Moreover, this blurring of what are 
often characterized as clear-cut categories is not, in fact, a new phenomenon. As Buddy claimed in his pilot performance, "I figure if the French can worship Jerry Lewis and the Turks can invent the croissant, anything's possible in this crazy, crazy world" ("Buddy Cole"). Such cultural intermingling, Thompson suggests, predate contemporary globalization.

Just as Thompson uses his camp persona to imbricate homosexual politics into racial politics, so too has the gay character of Buddy proven useful for interrogating mainstream biases regarding other sexualities. This methodology was perhaps most effectively demonstrated at a performance for the Just for Laughs Comedy Festival (circa 1993), with an audience less prepared for his shocking comedy than the regular viewers of The Kids in the Hall. In this particular skit, Buddy enters the stage on a stool carried by two male grips. He blows kisses to them and the rest of the audience, taking a moment to wave and smile at a man in the front row. He warms up the crowd, as most comedians do, by claiming to love Montreal. While most male comedians boast about the cities abundance of beautiful women or culture and nightlife, Thompson declares his love for its men. He claims that gay men have always flocked away from pretentious Toronto to Montreal in order to party. Through this suggested preference for Montreal to Toronto and French-Canadian culture to Anglo-Canadian, Thompson wins over his predominantly Quebecois audience and encourages it to take up bragging about Montreal's homosexuals, rather than its hockey team.

Although Thompson's monologue begins with kisses and compliments, his presentation of controversial cross-generational and childhood sexuality quickly polarizes the viewers - as can be seen by camera shots of the audience. His assertion that, at the 
age of twelve, he fell in love with a forty-year-old "boy" named Mario does not illicit applause and laughter from substantial segments of the audience. Nor does his explanation, "Now please, don't get all excited! I was a very well developed twelve. Technically I wasn't a minor, I'd been having sex since I was seven." Thompson's character claims that this experience of sexuality developed due to his international travels. These travels, especially throughout Northern Africa, have given Buddy a nonWestern, and thus "healthier" understanding of sexuality. Like most controversial comedic statements, however, this one has a double meaning. Because Buddy's parents were international diamond thieves, he can be seen as already corrupted by his family's involvement in sin and vice. Thus, his attitudes and experiences of sexuality are due either to his liberation from Western taboos through the privilege of diverse cultural experiences, or to his indoctrination into a criminal lifestyle at a young age.

Having been abandoned by his parents at Dorval Airport, the boy with a taste for an expensive lifestyle sets out to find himself a sugar daddy. Fortunately, Mario approaches him and offers five dollars for a nude photo shoot. Cole explains, "I said he could take the pictures; he just couldn't develop them in case I got famous. And I wanted ten bucks. No use showing your whole hand right away!" Notably, in this scenario, Thompson constructs the child as the agent of his own sexuality, and the pedophile as the exploited dupe. The young Buddy is willing to return to Mario's home not out of naivety, but because he intends to use his sexuality to obtain room, board and other rewards. This portrayal of a cross-generational relationship is one that leaves Thompson's audience members initially uncomfortable. As the monologue progresses, however, they appear to 
be won over by the fact that the boy, now a healthy adult sitting before them, appears perfectly self-aware, confident and not negatively affected by the experience.

Throughout the monologue, Thompson inverts the expected hierarchy of a pedophile and the underage object of his lust. It is the child after all who sets out to exploit an older partner. And in the end, it is Buddy who must face criminal consequences for his actions:

Mario was the most immature man I'd ever met, simple really, maybe border-line retarded. Let's face it, I was the top! But nothing lasts forever, not even love, which is where the Mounties came in. At Mario's trial I refused to testify against him, as did all the other boys in the neighbourhood and he was set free. I however, was sentenced to six months hard labour in a boy's work camp for sexual misadventure.

This monologue alone could not radically alter the way in which Thompson's audience perceived childhood sexuality or cross-generational relationships. It did, however, manipulate viewer's comfort levels. In the end, their own discomfort with the subject matter is the punch line. As Thompson charges, "I know some of you good citizens sitting there in your $\$ 37.50$ seats are shocked by my story of taboo love. But let's face it people, if Mario had been Maria, you'd all be celebrating my life in television movies." In the end, the viewer's discomfort reinforces the assessment that certain voices and experiences are erased from public discourse and popular culture due to their taboo nature. Thompson brings these issues and voices into the spotlight. While he does not necessarily succeed in diminishing their marginality, he does manage to upset the ease with which the audience accepts and privileges traditional partnerships and sexualities. 
As the performance at the Just for Laughs Comedy Festival suggests, Thompson pushes the limits of tasteful comedy, but he also displays a consciousness of his audience as heterosexual, white and middle-class. Similarly, in his pilot performance with The Kids in the Hall, Buddy follows up a particularly vulgar comment with the assertion, "I hesitated to use that analogy to a heterosexual audience." In truth, Thompson likely did not hesitate, but rather wished to acknowledge to his audience that he was well aware of their normative notions of acceptability. The claim also serves as a subtle wink from the comic to his viewers. Buddy concedes the vulgarity of his tactics, but also acknowledges that, despite being pushed beyond their own boundaries of decency and morality, the audience still enjoyed the joke. This perhaps leads us to question why the boundaries are there at all.

A general aim of this chapter has been to demonstrate that sketch performance, as a comedic method, often carries with it an implicit resistance to a dominant order. As I have demonstrated, however, Scott Thompson's "Buddy Cole" monologues are frequently self-referential, making this element explicit, most clearly in their undermining of mainstream notions of masculinity. Through his use of camp techniques to fuse gay political agency with other subjects, Thompson demonstrates the mutual contingencies among national, racial, and gendered identity tensions. By advocating for a politics of inclusion by problematizing past justifications for exclusion, he is able to move his work beyond being an analysis of mainstream notions of gender biases and heteronormativity to address other stereotypes and hierarchies. As I have noted, one of his most innovative demonstrations works around the essentialist clichés regarding homosexuality. Populist uses of camp and the gay subject such as the character of Buddy Cole can be criticized 
for often commoditizing and homogenizing queer identities. Thompson, however, challenges this view by demonstrating the phobic attitudes that still exist around the camp image of the effete, urbane, and aesthetic homosexual. By using this very stereotype as a camp tool for exploring a diversity of biases - including those of race, age, and sexuality - he effectively exposes the illogical tangle of identity formations underlying the overarching artifice of hegemonic coherence itself. 


\section{Chapter Two:}

\section{Political Satire and the Disruption of Masculinity in The Rick Mercer Report}

In the study of sketch comedy, camp is the most widely analyzed and perhaps most clearly political method of gender parody. This is not to suggest, of course that other methods do not warrant similarly close consideration. Rick Mercer's comedy, for example, is less camp than Scott Thompson's but has proven equally successful in questioning mainstream representations of masculinity and sexuality. In his portrayal of the middle-class patriarch of the nuclear family in contemporary society, Mercer reconstructs this most normalized of figures within the media as neither universal nor absolute. While Mercer's sketch comedy work is political, it is not explicitly queer in origin or intent, with its comments on gender norms generally proving more nuanced than camp material and therefore inviting a wider range of interpretations and responses from its audience. As I will argue in this chapter, mainstream culture today is more open to sexual diversity than the Western cultures that first gave rise to camp. Contemporary society is capable of sustaining a deeper queer political potential in subtler, indirect works such as the sketch comedy of The Rick Mercer Report.

Mercer made a clear decision not to present his personal life and motivations as causal in his comedic choices. Unlike Thompson, he does not foreground his gay identity within his work, even when this identity might be directly relevant to the content of a 
sketch. Mercer has claimed that he does not hide his homosexuality intentionally, but that his personal life is not relevant to his public persona (Gatehouse 40). This decision may perhaps reflect, in part, Mercer's concerns regarding the risks associated with making one's sexuality public knowledge, a move that - in the case of gay performers - can result in one being confined to fewer career options. While Thompson pushes willingly into this queer space, Mercer works to exclude his personal life from his media personality, so far as perhaps even to avoid playing gay characters. Both comics' choices, however, are relevant to a queer critique of normative masculinity because the material of both men - despite their differences - ultimately works to destabilize compulsory heterosexuality and homosexual essentialism. The view that there is no original gendered self preceding the comic embodiment of male identities allows both comics to map gender onto their bodies without necessarily accommodating the gender and sexuality adopted in private life. Mercer instils a sense of failure into heteronormative relations by parodying masculinity and heterosexual marriage in a way that underscores the artifice and problematic aspects of these institutions.

In a number of ways, Mercer's most popular comic character is distinctly different from Thompson's character of Buddy Cole. Throughout his work, Mercer uses the persona of the objective, white collar, reporter that is familiar to viewers as that which actual reporters often deliver. With his white shirt, dark suit, firm unemotional speech, and subdued style and enthusiasm, he projects an image of the conventional, middle-class male in control. This projection has become a standard persona in his latest production, The Rick Mercer Report, where he has reworked it into a salient critique of dominant assumptions regarding the privileged position of normative masculinity. 
In analyses of masculine performance as countercultural and queer, theorists have tended to focus on female enactments. According to Robin Maltz, queer gender performativity is bound up in the politics of social behavior as various expressions and acts which both reinscribe and displace what is deemed a "normal" gender/sex equation. The queer gender performativity of the stone butch enforces the binary of masculine/feminine but at the same time works against anatomic destiny. (275)

The term "stone butch" refers to women's performance of an unambiguous and uncompromising masculinity coded through familiar Western stereotypes of middleclass, often blue-collar masculinity. Although Maltz blurs conscious "performance" with subconscious or habitual "performativity," her analysis of the subversive potential of the stone butch as a form of parody is a useful appraisal of queering masculinity. ${ }^{7}$ However, she does not adequately incorporate theories of gender parody into her assertion that the drag king - whose conscious performances are temporary - provide a less salient disruption of normative gender relations than the stone butch.

If we take all unconscious enactments of gender as performatively constituted, then all stances against the standard sex/gender binary, whether they are correlated normatively with a natural sex part or temporary performance, should be considered potentially subversive and destabilizing tactics. Just as feminists have implemented analyses of camp performance into gender politics, male performances of masculinity such as Mercer's can sustain deconstructions of normative binary systems. Where performances such as Mercer's differ from camp is in the treatment of the male subject. While camp is always sympathetic towards that which is being exaggerated or parodied, 
Mercer is distinctly less sympathetic, and at times even antagonistic towards the heteromasculine body that he satirizes.

\section{Political Satire and the Role of the Masculine News Reporter}

In Canadian cultural production, political satire has long held a popular and valued position. In fact, it is often incorporated into nostalgic analyses of Canadian culture as distinct from that of the United States. The Canadian Broadcasting Corporation, for example, airs prime-time shows that openly ridicule the network and employs Mercer in the production of documentaries and political commentaries. Canadian politicians willingly participate in mock interviews and sketch routines that make fun of their own actions, political ideals and media campaigns. The popularity of such satire is impressive - especially given the relative marginality of other Canadian televisual productions. This thirst for political satire is apparent from not only the longrunning success of the Royal Canadian Air Farce, but also the popularity of the shows This Hour has 22 Minutes and The Rick Mercer Report, which satirize media production and the national, international and local political scenes. Mercer further capitalized on the desire for news, politics and satire in his television special Talking to Americans. In 2001, this show became the highest rated comedy in the CBC's history (Coulter 93).

Sketch parodies have become valuable components of the news media, with especially younger adults turning increasingly towards comedy, rather than mainstream news reporting, for information about current events. ${ }^{8}$ Mercer occupies this intriguing space between satirist and journalist, comic and critic. In a 1997 Maclean's article, Barbara Wickens notes that Mercer is "rapidly becoming a sought after voice on political 
affairs, having written pieces for both Maclean's and Time magazine" (42). This is of course in addition to being "one of the most recognizable young faces on television." The gap created in critical journalism since the corporatization of mainstream media and the subsequent decrease of investigative journalism is more and more often being filled by satirical critiques of both politics and soft news. Indeed, the overwhelming success of shows involving political satire has left many politicians asking to be mocked in order to augment their images in the mainstream media (Bergman, B. 73). Discussing 22 Minutes (which attracted two million primetime viewers in 1999), Mercer notes that, "when we started, Preston Manning's guys were threatening to sue us. Now they call up trying to get him on the show" (quoted in DeMont 76). While, given the context of this statement, one cannot assume that politicians were actually calling to solicit their participation on the show, it is true that all major party leaders have participated quite regularly in 22 Minutes mock interviews during press scrums at parliament. Most have also made guest appearances on the show, especially during election time.

Mercer's most profound demonstration of the power of satire probably took place during the 2000 federal election campaign, when he destroyed one of the Canadian Alliance's strongest platforms. For this campaign, highly conservative, anti-gay candidate Stockwell Day put forward what he called the direct democracy initiative, which would allow Canadians to petition for a referendum on any issue by obtaining signatures from three percent of the electorate. In response, Mercer started an online petition for Stockwell Day to change his first name to Doris. Within one week, a million signatures had been collected and Day, facing the destruction of one of his strongest policy 
platforms, decided to incorporate the parody into his own campaign, changing his theme song to Doris Day's "Que Sera Sera” (Bunner 2). Day lost the election.

\section{Satire and the Sanctity of the Family}

Mercer's challenge to Day's campaign was of course also a challenge to the conservative family values that Day supports, an issue that the comedian takes up elsewhere in his work. European and Euro-North American anthropologists have historically considered the nuclear family to be the standard model within Western societies. More recently, this position has been questioned by contemporary sociologists and feminist scholars, and historians have demonstrated that the model did not attain notable distinction until the rise of the middle class in the nineteenth century, attaining its greatest force as the preferred family model in the mid-twentieth century. Nevertheless, conservative groups and some more traditional academics still consider the nuclear family structure the most functional environment for childrearing, and the most essential unit of social governance (Baker 73).

The nuclear family's symbolic peek occurred in the 1950s and 1960s, marked by television shows such as Father Knows Best and Leave It to Beaver. Ironically, soon after the male breadwinner was supposedly at the height of his cultural authority, television fathers and husbands were increasingly portrayed as inadequate misfits. In Honey, I'm Home!, Gerard Jones tracks American situation comedy from its origins in the 1950 s to the end of the 1980s. While he finds that a majority of family comedies worked to reinforce the idealized nuclear model and the American middle-class suburban dream, a few productions questioned this ideal. Consider, for example, the 1950s situation comedy 
Honeymooners, derived from a sketch comedy routine, which centred on a working-class husband and wife, Ralph and Alice Kramden. The premise of the show is that Ralph is discontent with his lot in life and is constantly attempting to escape this pit of mediocrity. Ralph firmly believes that he is the head of the household, his one source of a sense of authority and control. The audience, however, perceives that he is incompetent and often makes bad choices; indeed, his wife is marked as distinctly superior in intellect and competence. As Jones notes, this disharmony between his prescribed role as patriarch and breadwinner and his actual identity as an angry, bumbling male provides the central comic spectacle for the show, which was highly successful among middle-class viewers themselves (110).

The popular image of the incompetent, slightly idiotic patriarch was repackaged in the 1960s with the production of the cartoon hits The Flintstones and The Jetsons, and in the 1970s with All in the Family (Jones 169). Ralph Kramden, Fred Flintstone, George Jetson and Archie Bunker all present anxieties regarding their ability to fulfill the role of family leader and provider. The audience, of course, is supposed to find their inabilities humourous but, despite this apparent deflation of the patriarchal image, these comedies implicitly reinforce the nuclear family model. Although mocking the patriarch and thus suggesting the potential devaluation of this particular masculine ideal, such comedies ultimately uphold the status quo by depicting such men, however incompetent, as admirable for at least attempting to attain better lives for their families.

The image of the nuclear family and the father-figure portrayed in these situation comedies are precisely the subject of Mercer's satires. His sketches not only expose the inaccuracy of this narrowly defined image of family, but also highlight its inadequacies. 
Like other news satires produced by the $\mathrm{CBC}$, The Rick Mercer Report is part of the lateevening primetime schedule that precedes Canada's serious news program The National. This satirical news block occupies programming space generally reserved on American networks for popular situation comedies, while American sketch comedy and news satire are associated with a late-night rather than primetime tradition. The most satirical components of The Rick Mercer Report are the mock commercials, public service announcements and government campaign ads interspersed amongst the featured segments of the show. Generally non-partisan, the advertisements draw attention to various issues such as government corruption and social conservatism. They ridicule both the private and public sectors, as well as all of Canada's political parties.

Satirizing our white, patriarchal social structures including that of the traditional family, the sketches generally promote minority and women's rights. Throughout his career, Mercer has shown an acute understanding of women's rights and the feminist movement. His assessment of the nuclear family and the position of men within that model are derived directly from feminist accounts of the private sphere. According to Ann Pellegrini, since the end of the Second World War, the traditional family has undergone quick and major changes:

The family idealized under modern forms of U.S. capitalism is . . caught in a series of contradictions. On the one hand, changes in the organization of labor and capital undermine the family by taking away its economic rationale; on the other, family has become enshrined as emotional and psychic glue, the place where our need for stability, love, affection is nurtured, and the only place where it can be nurtured and satisfied. (137) 
Mercer's evaluation of the nuclear family draws attention to these contradictions. In response to conservative desires to maintain the traditional definition of marriage, for example, he created a mock public service announcement for the protection of all things traditional. ${ }^{9}$ In "I believe in the traditional definition of family," Mercer portrays a father frustrated with recent attempts to alter traditions and bestow increasing rights upon nonwhite, non-male and non-heterosexual members of society.

In this sketch, the viewer is presented with a stereotypical picture of white middle-class family life. The father - taking up the foreground of the scene and being the only speaker - appears in a white dress shirt, sweater and plastic framed glasses. His wife and two children remain in the background where they silently complete mundane domestic chores such as folding laundry. The mother and daughter are dressed rather conservatively in skirts and blouses and the son is clothed in imitation of his father. Closely mimicking contemporary conservative discourse on gay marriage, the patriarch begins with the declaration, "I believe in a traditional definition of family." He continues, "Traditionally, marriage was between a man and a woman." This assertion is within our contemporary understanding of the major political issues being debated, but then audience expectations are undercut when the character adds, ". . of the same race." By expanding the character's dedication to tradition, Mercer foregrounds the continuum between racism and discrimination based on sexuality. His presentation of the nuclear family and its entrenched spokesperson highlights its present-day advocacy of "tradition" as outdated and culturally insensitive.

As the sketch continues, this critique of the patriarchal nuclear family is reinforced by the speaker's promotion of the traditional definition of bastard and the 
constitution of women as men's property. The central character does not specify whose tradition is being upheld. He laments a range of lost customs, such as no longer being able to beat children, Sikh's being allowed to wear turbans in the R.C.M.P. and the House of Commons, and the legal redefinition of women as persons. He concludes his monologue with the stern warning, "if we keep going the way we are now, eventually everyone will be equal. And then what?" It is this unproblematic appraisal of the goal of equality, as if it is a negative oversight which we ought to avoid, that most blatantly challenges traditional interests. Mercer undermines the presentation of conservative ideals of family, gender and sexuality as common sense by simply presenting them in a more blatant form. He mimics the social values that contemporary social conservatives endorse, but renders them absurd by situating these views within a more transparent narration. Mercer renders this ideal absurd, but it is one that nevertheless pervades many contemporary discourses on family. He presents as unworthy of lament the end of a tradition in which the father's authority over wife and children was taken for granted.

In another sketch, Mercer extends his analysis of domestic relations to the father/son bond, with the image of the patriarch's masculine authority remaining the key target of comic deflation. "Satellite theft - it's not like stealing candy from a baby" opens with a father reprimanding his son for stealing a chocolate bar. When asked where he got the idea that stealing is acceptable, the son reminds the man that their satellite signals are, in fact, stolen. As in the previous Mercer sketch, the father is dressed in a plain dress shirt and tie. His unkempt hair accentuates his lack of style - a stark contrast to the camp technique of stylistic exaggeration used by Thompson. This sketch, like the real-world commercial it parodies, implies a natural responsibility for the parent to act as a positive 
role model for the same-sexed child. Mercer, however, refuses to allow this scenario to remain an implicit reinforcement of heteronormativity. Rather than take his son's point, that theft is theft regardless of scale, the father becomes spiteful. Unhooking the stolen satellite, he declares, "I hope you like the CBC!" As punishment for overtly acknowledging his father's duplicity, the son is left with only one channel and forced to watch "Marketplace" and a Town Hall on menopause. The patriarch is shown to be unworthy of the privileges that come with the masculine authority and role as provider that he has falsely assumed. He proves inadequate, moreover, at socializing his son into his own eventual adult privilege as patriarch. Perhaps most importantly, the unfulfilled demands of the ideal fail to allow Mercer's character to have any sort of healthy relationship with his son. In attempting to direct his child toward fulfilling these same unrealistic and inhumane ideals, the character ultimately only alienates himself all the more.

Mercer pushes the image of the dysfunctional male even further in the sketch "Sometimes airlines die and go to heaven." In this fake commercial, a father attempts to explain to his son that their trip to Disneyworld has been cancelled due to the bankruptcy of an airline. He addresses the situation in the same stereotypical and scripted way a father might broach the subject of the death of a grandparent. The son's angry reaction makes it obvious that this attempt at meaningful communication fails. While the commercial is promoting the importance of talking to children early about airline failures, the son shows a level of sophistication that children are traditionally not acknowledged to have. In response to his father's attempt to explain the choices of Jetsgo head Michel Leblanc, the son cries out "that's the third airline he's messed up already!" This sketch 
addresses the father's inability to educate his children not only in survival and social skills, but also in major moral lessons. While the adult makes excuses for the behaviour of airlines and LeBlanc, the son presents a firm and pragmatic comprehension of the situation. As he argues, high fixed costs and fluctuating fuel prices can be planned for and LeBlanc, not the industry, is at fault. The father's denial of Leblanc's business incompetence is echoed in his inability to perceive his own inadequacy in the roles of father and patriarch. This function of the parent as an infallible socializing force is shown, by Mercer, to be an inaccurate conceptualization of the division of knowledge and power between generations. Moreover, the sketch suggests the ways in which the hierarchical family model that engrains the adult male as supreme functions to sustain the middle-class economic system itself, a system that privileges men's activities as "providers" within the more public realm of business.

It is through the traditional image of husband as provider that Mercer most effectively extends his critique of the patriarchal chain of economic control to address its impact on women. In the government service satire "Improving the lives of women across Canada," a female spokesperson for the government of Canada professes a commitment to improving the lives of women. As she explains, in addition to a national daycare system, the government has decided to introduce a national husbandcare system. Husbandcare venues will be equipped with Lazy Boy recliners and big screen televisions; lunch will consist of beer and pickles, and men will be provided with do-it-yourself projects that, of course, can be started and not finished. Husbands will be taken on supervised group excursions to fishing shows and stereo shops. This monologue is accompanied by the image of a group of men lined up and holding a rope, as is often used 
by daycares to keep children from wandering off. The men look awestruck, excited and intimidated as they walk about the busy streets of Toronto with only a few daycare attendants to keep them safe. The sketch concludes with the assurance, The first time you drop your husband off, he might be scared and confused. But rest assured, by the end of the day, he won't wanna leave... but you'll make him. Canada's National Husbandcare Program - ladies, think how much more you'll get done without the ball and chain.

With the terms "ladies" and "ball and chain," the sketch invokes a conservative and gendered language traditionally used most often by men to describe their wives. The inversion of the application of the terms here foregrounds the advertisement's questioning of patriarchal ideals. Similarly, this sketch also presents an inversion of the power roles found within the traditional family and heterosexual relationship. Distracted by her career, the wife no longer has time to nurture and care for her husband as much as she used to. Unable to look after himself, the man is sent to a daycare, taking up a position not only beneath that of his wife but that of his children as well.

As Mercer suggests, within contemporary Western society, new notions of sexuality and new opportunities for women have presented themselves. However, new conceptions of family and the reworking of mainstream male identity have been slower in their development. Statistics have shown that, even with full-time jobs, women are still largely responsible for childcare and other forms of domestic work. This inequality has proven a major factor in the lower rate of remarriage for divorced women as compared to divorced men (Baker 108). As women become increasingly independent from men financially, they also become less interested in the emotional burden of childcare and 
husbandcare, which have been associated with women's marital roles. Mercer's sketch implies that men have yet to adapt sufficiently to these equalizing shifts. Not only are hetero-masculine men not taking on more of their share of childrearing and other domestic responsibilities but, as Mercer suggests, their own unjustified expectations of full-time care are becoming absurdly obvious. In his husbandcare sketch, men are left stranded, with the financially self-sufficient women no longer relying on their domestic roles to buy monetary security, even though they are still not permitted to take on the dominant role of provider within the traditional heterosexual model. Thus, in the sketch, women cast off their role as the maternal caregiver, and leave their helpless husbands in the care of paid professionals.

Mercer uses a mainstream venue to demonstrate not simply the performative quality of gender, but the crippling effects of assumed masculine authority on females and males alike. His sketches do not represent current conceptions of heterosexuality and the family; rather they offer critical narratives that deconstruct assumptions that are often seen to give men privilege. Through exaggerated imitations of contemporary signifiers of a middle-class masculine identity within the traditional nuclear family model, the comedian encourages his audience to confront the artifice of this identity and the damage it fosters. Mercer's sketches imply that the identity of the father/husband does not function as a site of caring and protection for all the other members of society; wives and children appear to have adapted well to the new economy. Rather, those in the father/husband roles are the ones who are most dependent on the nuclear family system. Similarly, Mercer's husbands and fathers imply that feminism and homosexuality are not 
the reasons for the dissolution of the nuclear family. Rather, it is the systems of male privilege and heteronormativity, and their inability to adapt to new economic conditions such as women's financial independence, that have fostered current social disruptions.

Mercer's comic portrayal of men's masculinity and heteronormativity is not explicitly queer. By parodying dominant masculine codes, however, he implements a technique of negating notions of originality that have proven especially effective for developing queer identity politics. In this sense, Mercer's performance is sympathetic to the camp technique of imitation and exaggeration, and he counters the notion of homosexuality as a form of social inadequacy by demonstrating the failure of the identity of the traditional family patriarch. This presentation of male "lack" also functions more generally as a critique of broader theories of society and media. Although Mercer does regularly comment on the inequalities faced by women in politics, he more often presents male characters as less capable and less respected than women, as the "husbandcare" sketch makes obvious.

According to Moe Meyer, camp makes it apparent that beneath the surface of any identity performance is not an original, but merely another performance. Mercer, however, in his appraisal of masculinity, presents a model of maleness that has no hidden surfaces. Once the layer of the patriarch and provider is punctured, Mercer's characters seem to have no other identity on which to fall back. In this light, his critique is of some men's narrow reliance on masculinity for their identity, a situation that leaves them vulnerable. The shallow role of the male provider within the nuclear family framework is not sufficiently complex and malleable in its engagement with gender renegotiation and the new economy. This is a situation that Mercer implies needs to change, as attempts to 
preserve normative masculinity by invoking mythic notions of tradition prove to be steeped in unreasonable and ultimately unsustainable arguments. 


\section{Chapter Three:}

\section{Steve Smith's Red Green and Playing Possum with Masculinity}

In the culture of male parody, there is perhaps no character more associated with Canada and masculinity than comedian Steve Smith's Red Green. Like the moose, the lumberjack and the beaver, Red has become an internationally consumed sign of the Canadian outdoors. ${ }^{10}$ Like Thompson in his "Buddy Is Canadian" sketch, Smith mocks the stereotype of Canadian masculinity as necessarily outdoorsy. Furthermore, in The Red Green Show, Canadian masculinity is jokingly portrayed as tough, uncivilized and, by all accounts, absolutely incompatible with femininity. Smith presents his identification with rough wilderness masculinity, however, almost entirely through parody. Like all members of the fictitious Possum Lodge, Red offers an image not of masculine perfection, but of a bumbling and inadequate man whose attempts at machismo fail again and again. His red and green plaid shirt might, at first glance, imply frontier masculinity, but they are soon recognized as actually representing only the theatrical enactment of the ideal. It is a costume easily donned, just as Smith, through his ready exaggeration of male identity, reminds his audience that no authentic image of masculinity or Canadian identity exists. In this chapter, I demonstrate that Smith's strategic performance of Red Green is in fact an innovative adaptation of camp that has been made feasible only in recent times. Smith presents a form of parody, I argue, that, while masculine and 
heterosexual, accords with camp in its intent of combating cultural marginalization through a sympathetic depiction of a particular gender identity.

The changes that women's identities and that of the nuclear family have undergone over the past half-century have worked to destabilize somewhat men's masculine personae. Although patriarchy and compulsory heterosexuality are arguably still dominant, feminism and queer activism have assisted in the gradual marginalization of conventional male heterosexuality. As a result, a space has opened up within gender performance that allows for the representation of a marginalized hetero-masculine identity such as that embodied by Red. Steve Smith's work, however, is not an interrogation of feminism, but instead a questioning of the rigidity of masculinity. In contrast to much of contemporary situation comedy, which appropriates feminist satire in order to reinforce hegemonic masculinity and heterosexuality, the Red Green sketches do not offer an idealized metanarrative of either the masculine male or traditional nuclear family. ${ }^{11}$ Instead, Smith's non-queer, masculine gender performance works to deconstruct sexual norms and hierarchies.

\section{Green Masculinities in the Contemporary Mainstream}

The identity presented through the character of Red Green conforms to a male identity that has dominated much of the twentieth century. It represents a common, historically prevalent version of maleness - that of the masculine, heterosexual man. However, Smith's sketches do not wholly support compulsory heterosexuality, whereby alternative sexual choices, identities and practices are marginalized or erased. Instead, Smith's work acknowledges a more ambiguous attitude toward masculinity in general. As 
Maurice Berger, Brian Wallis and Simon Watson note, in today's Western society, masculinity is not easily defined:

it is no longer possible simply to declare one's manhood as a form of identity politics. Masculinity, the asymmetrical pendant to the more critically investigated femininity, is a vexed term, variously inflected, multiply defined, not limited to straightforward descriptions of maleness. (2)

This image of contemporary masculine identification as fluid is supported by Smith's presentation of the traditional norm of the manly individual as laughable not only in its inadequacy, but also in its suggestion that such a gender model could ever have been seen as a foundation of social order. Smith's portrayal of maleness does not hearken back to a pre-feminist golden age of patriarchal control and rigid gender definition. Rather, it exposes the artificiality of the very notion of a universal or ideal masculinity.

In its approach to the conventional middle-class, Canadian male image, Smith's performance of the character Red Green accords in important ways with feminism and queer politics and signals its potential alignment with camp. In contrast to the men's rights movement of the 1990s, Red is not meant to promote the authority of the traditional model of male masculinity; the character merely sympathizes with it, or finds in it a protection from other cultural forces. Like camp's use of femininity, Smith's performance of masculinity does not enforce an essential conflation of gender and sex, but interrogates the performativity of familiar images of the modern man.

Jack Babuscio has defined camp's most basic features as irony and humour. $\mathrm{He}$ argues that, through a gay lifestyle and the enactment of camp, one can critique and even reject dominant cultural assumptions about masculinity and sexuality (24). While the 
performance of masculinity at Possum Lodge is not explicitly queer, it does accord with Babuscio's analysis and encourages the viewer to see camp political strategies as potentially addressing recent attitudes toward established heterosexual male identities. Just as the camp drag queen is explicit in the intensity of her feminine posturing, Red is presented as thoroughly, almost absurdly, masculine. To the audience, the extremity of his performance leaves this stereotypical male comically inadequate. Utterly masculine in an increasingly unsympathetic world, Smith's Red comes across as marginalized, yet still symbolically forceful due to the legacy of patriarchy and heteronormativity. The new marginality of this type of male creates a space for a sympathetic performance, while the lingering authority associated with the identity provides incentive for a radical critique of the sexual hierarchy.

\section{Father Doesn't Know Best}

Red Green, similar to Rick Mercer's father characters, is to a certain extent, a continuation of the bumbling patriarch presented in The Honeymooners and The Flintstones. In a similar genre, and perhaps more relevant to the themes of The Red Green Show, feminist satire combined with the men's rights movement of the early 1990 s to create what Robert Hanke calls "mock-macho" situation comedies (77). One such show is Home Improvement, which presents a nuclear family whose comic experiences arise when domestic harmony is disrupted by the father's thoughtless machismo and failed attempts at home renovation. According to Hanke,

By making a mockery of masculinity, these comic narratives simultaneously present men as objects of laughter and as subjects moving between "old" and 
"new" subject positions. While this process of resubjectification may not signify a change in social structures of hierarchy and inequality, such comic texts can imply a lack of reverence for conventional masculinity, especially as it is defined in terms of competence and infallibility. (77)

Like the mid-century sitcoms focused on blundering patriarchs, "mock-macho" comedies only superficially question the standard image of male authority within the nuclear family. The plot of these comedies runs roughly as follows: the patriarch undertakes some scheme that he believes will help his family. The scheme usually contradicts the demands of his wife. The scheme fails and the wife is scornful. At the end of the half hour, the situation is somehow ameliorated and husband and wife briefly return to marital bliss. The domestic male is presented as comically insensitive and incompetent. Nevertheless, the nuclear family and the genders and sexualities that support it are glorified as necessary cornerstones of modern society.

In The Rick Mercer Report, Mercer satirizes the presentation of masculinity as at once flawed and ideal. Mercer's racist father figure echoes past patriarchs within this tradition such as Archie Bunker from All in the Family. Rather than reinforce this characterization as worthy of admiration, however, Mercer presents a biting critique of hegemonic masculinity and the sexism and racism that it supports. Steve Smith's sketches are tellingly different in their approach. The father in Mercer's sketch is confused by the social changes of the past few decades and Mercer shows no mercy in his satirical critique of the traditional paternal role of master and provider. Smith also makes fun of the incompetent, middle-class heterosexual male. Unlike Mercer's characters, however, Red Green and the other men of the Lodge are so pathetic in their inadequacy 
that they gradually gain the compassion of viewers, especially those who self-identify as average and traditional. While coming across as being just as racist, sexist and conservative as the Mercer characters, Red's flaws are portrayed through far less cynical parodies. While the character's ignorance is mocked gently, his bizarrely high level of incompetence leads any viewer to assume that Red is not capable of promoting or implementing his oppressive values except as a feeble reinforcement of stereotypes.

The character of Red Green is a recent addition to the longstanding comic tradition of hapless patriarchs. However, in contrast to characters such as Ralph Kramden and Archie Bunker, he embodies a viable critique of hegemonic masculinity. The characters of the $1950 \mathrm{~s}, 1960 \mathrm{~s}$, and 1970 s were comic due to their inability to succeed in a world in which domestic and economic controls were seen as men's inherent rights. Smith's character is not given such an opportunity. Instead, he is marginalized by a modern world that does not understand, appreciate, or wish to accommodate the likes of him.

In contrast to the depiction of patriarchs in the situation comedies from previous decades that I have mentioned, the performance of Red Green more forcefully interrogates the assumption behind normative masculine identity. This is done most blatantly by Smith's signalling of his awareness of his gender performance. Despite the fact that Smith presents a version of what most would see as an average Canadian male, Red would not be considered "normal" by most North American viewers. His largerthan-life characteristics emphasize the constructed nature of Red's masculinity in much the same way that camp highlights incongruities between biology and performativity. Smith's work cannot be readily defined as a standard example of camp because it lacks 
historical concordance with gay or queer politics; however, it does make use of most of the key techniques found in camp works, such as many of Thompson's. Moreover, it does so in order to offer a sympathetic spoof of the traditional heterosexual male who feels marginalized or at least dethroned within contemporary Canadian society. For these reasons, the "Red Green" sketches can be usefully described as examples of male heterosexual camp.

\section{Duct Tape and the Preservation of Masculinity}

The character Red Green emerged as a regular sketch on Steve and Morag Smith's 1980s comedy show Smith and Smith. As the leader of Possum Lodge, a northern Ontario lake community, Red provides advice on marriage, fishing, and carpentry to a hypothetical group of men who, it is presumed, are not sufficiently good at any of these things. He presents his audience with a stereotypical backwoods masculinity reflected in everything from his daily activities to his standard red and green plaid shirt, an item of clothing that has often acted as a generic icon of Canadian, masculine identity. Smith and Smith was followed by The Red Green Show and, over its more than ten seasons on the air, the latter has made a complex comedy out of a masculine retreat from a fast-paced, high-tech world. As the program grew in popularity throughout the mid-90s, media critics were quick to associate the show with a reinforcement of traditional masculinity. In 1996, Esquire wrote that

The New Red Green Show has steadily built a loyal, guy-filled audience.

Think of it as Home Improvement folded into a Bob and Doug McKenzie routine, with Canuck TV veteran Steve "Red" Smith dead panning woodshed yarns and 
advice about how to use duct tape to convert your rusty old pickup into a homeentertainment center. Well worth scouring the TV listings to find, but don't expect the wife to join you on the couch. (28)

This appraisal presents Red as appealing to a male audience and implies that the show reinforces both hetero-masculinity and the gendered division of comic taste. The producers of the show, however, perceive their audience differently. In a 1997 article, Karen Bell argues that the show is, in fact, well received by women: "Hugely popular with North American audiences, the Red Green fan club has over 80,000 members. Many are women from all walks of life.... This is because the show is really tough on men. [Co-writer Rick] Green calls it a 'show about the idiocy of men"' (46). It is my contention, however, that the mockery of men is not as aggressive as Bell and Green propose.

Red Green's attempt to appeal to a female audience is further evidenced in its comic characterization of maleness. In Hindsight is 20/20, a retrospective mockumentary, the narrator of the show describes Possum Lodge as

a club on the shores of Possum Lake where men are men and mother nature is frightened. Possum Lodge, where men still live by traditional values like Druids or Vikings. Possum Lodge, the last place on earth you'd expect to see on television - especially public television.

The men of the Lodge are similarly presented as living in the past and in tension with the fast pace of contemporary city-centred society, as well as the supposedly feminine natural world in which they choose to pursue their Lodge life. 
The tension between Mother Nature and manliness, however, is not altogether upheld, although this dissidence is itself disrupted somewhat by the fact that the character who proves to be least compatible with the feminine world of nature is the Lodge member who is himself most feminine - Red's nephew Harold. Harold's characterization as gentle and out of place provides a sharp contrast to Red's backwoods masculinity. Harold separates himself both from nature and his Uncle Red through his constant use of digital technology. For example, he is frequently seen carrying an electronic, editing keyboard with which he manipulates the fictional Red Green Show, and is therefore able to control his immediate surroundings which consist of the show's set and characters. As producer and director of the show-within-the-show, Harold is the nerdy and awkward underdog who is responsible for keeping Red on the air. In the mockumentary, the audience discovers that it was Harold, not Red, who got public television to take on the show and who has made all of the major programming decisions that have allowed it to remain popular with viewers. According to Harold, his reason for promoting the television show was that he hoped it would force Red to change:

I've always found Uncle Red to have certain attitudes that are kind of quaint, in a racist, offensive way - sort of politically incoherent. But I thought if I could capture that on television the viewers would force him to change. Ya know, it's easier than trying to talk to him.

Harold notes that his show is a success not due to its complexity, quality, or desirable representation of maleness; rather, it is popular amongst audience members who actually have a negative reaction to Red and the other Lodge members. In reality, meanwhile, the actual show that appears on $\mathrm{CBC}$ has proven popular not because of the audience's 
affinity with the Lodge leader, but due to Steve Smith and the other creators' ironic positioning of Red Green's male identity.

Despite its appeal to a stereotypical masculinity, Red himself asserts that the Lodge is not a boys' club, nor an otherwise sexist environment. He claims that, for some inexplicable reason, women simply do not show an interest in the activities that the Lodge offers. Harold, as the more intelligent and sensitive character, is constantly apologizing to viewers for his uncle's outdated attitudes about women. In one instance, for example, Red justifies Lodge activities with the argument, "I think it's a guy thing. We have no trouble blowing off a Saturday morning converting a hot-water heater into a one-man sub. I don't see too many women doin' that." Harold, in an effort to moderate his uncle's simplistic gender views, quickly adds, "What my uncle means is, uh, these are things that women choose not to do. They are certainly every bit as capable as men are. If not more so." Although Harold's contribution sounds somewhat like lip-service or the mouthing of politically correct clichés, the view that women are equally capable is further reinforced when a woman beats a group of men in the Mr. Possum Lake Competition. Notably, Harold attempts to justify his own loss by explaining that, on the day of the competition, he was retaining water. Ordinarily, in popular media, a woman's success in a male-dominated competition would be presented as surprising. However, the absurdity of Harold suffering from water retention - a condition generally recognized as a female menstrual affliction - reconstructs this female victory as mundane. This deflationary gesture undermines both Harold's identification with maleness, and women's subordination in masculine competition. Rather than act as a reinforcement of a separate 
masculine sphere, women's general absence from the show implies the undesirability of life at the Lodge.

Although Red is happily married, most of the show's other men are single, divorced or extremely unhappy with their marital situation. As the character Dalton Humphrey notes, "when they say for better or for worse, there's no limit to how much worse." In a sketch addressing the disharmony of marriage, the show's mailman laments his divorce not for emotional or financial reasons, but because it has forced him to postpone the renovation of his boat. In another sketch built around a word-game, in which Red provides clues for Dalton to guess the word "divorce," the show implies that, contrary to many media representations, the ideology of the nuclear family is not universally accepted or experienced. Dalton's response to "the opposite of married" is not "divorced" but, rather, "happy." Similarly, for the character Mike Hamar, an ex-convict who grew up with a single mother, Red's prompt "another word for daddy" does not elicit the response "father," but the term "lifer." Through such misunderstandings, The Red Green Show demythologizes the universality of the nuclear family model. Notably, Dalton - an "average" husband - does not self-define first and foremost by his marital status. Although he is unhappy in his marriage, the rational action of filing for divorce is evidently not realizable. This might be related to the ex-convict's conflation of marriage with prison life; both institutions are presented as ones that men enter unwillingly, as if they are imposed on them by some higher authority. Of course, in the case of marriage, the imposing authority is ideological; it does not physically exist. The marital requirement, like the fulfillment of gender roles, is self-policed. These men have been duped into duct-taping together a masculine identity that they themselves find 
uncomfortable. The awkward scenario is exacerbated by the viewers' gradual realization that the obligatory masculine roles that the characters are expected to perform through fishing, recreational vehicle restoration, and so on are not particularly useful in contemporary society.

In The Red Green Show, duct tape abounds, frequently functioning as a comic signifier of the male characters' inability to address contemporary social problems such as an unhappy marriage in a substantive and permanent manner. A quick and shoddy fixit job is always at hand to solve any mistake or ameliorate any breakdown, but never with any degree of permanency. Red's saying, "if the women don't find you handsome, they should at least find you handy" implies the imperfection of these gender constraints. In this case, Red counters his failure to be attractive by repeatedly trying to cover up this lack through a demonstration of handiness. However, Red is not particularly handy. Like duct tape, his physical capabilities are only a temporary suture of his inadequacies. It does not offer any sustained masculine control or order. As gender roles have changed during the latter half of the twentieth century, notions of acceptable masculinity have undergone a similar patch job. The irony of this superficial revision to hegemonic masculinity is that, like Red's tape-strapped projects, it does not present a coherent, unified surface for evaluation. The Red Green sketches encourage the audience to acknowledge this temporary and inadequate fix-it job not only in Red's projects, but also in the contemporary construction of masculinity that the projects symbolize.

Notably, while the show generally addresses traditional marriage as an institution that fails to remain coherent in light of recent gender developments, several characters in the show choose to remain married. This is the case for Red and Bernice, as well as for 
Dalton and his wife Anne Marie. The women in these relationships are never seen, but it is implied that their decision to remain married to Lodge men is not necessarily a rational one. The fact that women are attracted to such men is itself depicted as a failing. For example, in a sketch in which Dalton attempts to sneak into the house after a late night at the lodge, he puts on a friend's pyjamas hoping this will lead his wife to think that he was already in bed and just got up to investigate a noise. Anne Marie is, of course, not fooled for a minute, demanding, "Dalton, why are you wearing Buster Hattfield's pyjamas?" And yet, although Dalton's wife is presented as clearly not attracted to him, it is implied that she is having a relationship with another equally pathetic and incompetent member of the Lodge. Much like Alice Kramden in The Honeymooners, wives in The Red Green Show function as wise-cracking critics of male posturing, even as they simultaneously discourage utter hostility. However, in the latter production, the equalization of genders is accepted rather than comically threatened, as it is in The Honeymooners, with wife-abuse.

The contemporaneousness of Red Green's politics is perhaps most blatantly presented in its relatively casual attitude toward homosexuality. Unlike many situation comedies, the show does not disparage homosexuality as a way of reinforcing heteronormativity. ${ }^{12}$ Instead, it negates both heterosexual and homosexual desires by presenting Red and his friends as undesirable by all accounts. In one episode, a Lodge emergency forces Red and Dalton to spend the night in the same bed. Red turns to Dalton who is lying behind him and demands, "Dalton, What is that? There's something cold in the bed." Dalton explains that it is his tire iron, which he sleeps with for protection. Retrieving the iron and placing it under the bed, Red responds, "I don't find ya that attractive, Dalton." This scene understates Red's reaction to homosexuality. That he is 
not interested in Dalton is not a consequence of their heterosexuality or of the fact that they are both married; rather, Red simply does not find Dalton very appealing. Articulating his aversion as being to Dalton as an individual, rather than to homosexuality in general, Red implicitly acknowledges his own bisexual potential. The heavy-handed phallic symbolism of the tire iron, meanwhile, signifies Dalton's sense of always being under possible threat from other males. Notably, like Thompson's Buddy Cole, Red uses humour to emasculate the other character and regain power within a scenario that threatened to leave him quite vulnerable. As with gay culture, comic deflation proves an effective tool for some heterosexual males in attaining or sustaining their authority.

The masculine vulnerability that permeates the show is perhaps most apparent from the men's explicit performances; it is implicitly signalled, however, through various symbols, including that of the Possum Lodge mascot. This humble marsupial does not strike one as an especially virile or majestic creature such as the elk, buffalo, and other animals often used to symbolize all-male cultural communities. And yet, the possum is peculiarly appropriate as a signifier of the masculinity of Red Green's lodge buddy community. As the show's writers note,

the possum was chosen as the icon for the organization because of its abhorrence of violent and destructive confrontation. The clever possum solves its problems through a cunning ruse known as feigning death. The founding members of the Brotherhood pledged to avoid confrontation and seek compromise thus making the possum the ideal symbol, lying on its back with its legs in the air - the internationally accepted compromising position. (Smith and Green 7) 
Like the possum, the men at the Lodge are slow, inactive, and usually solitary. Their inability to solve problems through communication echoes the possum's dislike of confrontation; this male avoidance of dialogue is implicitly associated with domestic antagonism, with Red being the only Lodge member who has a positive and honest relationship with his wife. The desire to avoid conflict implies that the other men in the show have turned away from - or perhaps never actually felt - the assumed masculine urges to wage war and to conquer nature and femininity.

"Playing possum" refers specifically to the animal's apparent tendency to feign death when it feels threatened, and is now a common metaphor for avoiding conflict. In fact, the possums' safety strategy has lead to them frequently being killed by passing traffic. In reference to The Red Green Show, the phrase implies not only the vulnerable and compromised position in which the men find themselves, but also the dangers of their unconscious performances. Threatened by the modern world, the men of Possum Lodge turn their backs on contemporary society and revert to a traditional identity model. Steve Smith and Rick Green suggest that the performance of outdated gender might actually contribute to the men's downfall by advancing their obsolescence.

Smith and Green, however, are sympathetic to their characters' plight, and therefore offer suggestions for ways in which the possum might still be found useful. For example, Red offers the following advice on turning a possum into a pet:

1) Possums are untrainable, disloyal, and pretty stupid. 2) They are not shy about relieving themselves. But here's the good news - they're edible. If you're still convinced you want a pet possum, you can look forward to several years of a onesided and extremely unfulfilling relationship. (Smith and Green 7) 
Although these animals are described here as basically undesirable and self-centred, Red remains confident that some people will still want them around. Thus Smith and Green, while critical of rigid male gender conventions, suggest that men conforming to these conventions can still find an accommodating space within society. The men at the Lodge, like the placid possum itself, are portrayed as inept and timid. In accord with camp sympathy as theorized by Meyer, Babuscio and others, Smith and Green use a gentle parody that depicts traditional men not as violent or threatening, but as charming incompetents that warrant above all else nurturing and support.

My principal argument in this chapter has been that, while scholars to date have worked to sustain camp's historical association with gay and queer identity struggles, recent developments in the gender and sexuality politics of North American society have created a marginalized heterosexual male image that has gained acceptability through a form of sympathetic comedy akin to camp. In his study of boys' identification with masculine Hollywood screen heroes, Robert Lang suggests that, in this relationship, we have "a male interest in what seems to be male; an interest in masculinity - accomplished through looking at another male, in an act of identification" (2). Red Green (and to a lesser extent Mercer's characters) does not provide this eroticized space for identification. Because the parody intrinsic to sketch comedy encourages the viewer to see the artifice of identity, erotic identification is disrupted. But empathy, especially in the case of Smith's work, need not be disrupted in the same way. The political utility of Smith's parody is comparable to that of camp but ironically, in order for it to be effective as a defence of a traditionally dominant gender model, Smith must strip Red Green of any sexualized 
potential. The Red Green sketches are not aimed at embodying the erotic masculine image of Hollywood cinema and mainstream media and advertising. Close consideration of Red's exaggerated persona reveals, however, that it is performed with critical intent, even while still encouraging some form of male-male identification and admiration.

By performing the excesses of masculinity, Smith disrupts the linking of biology with gender destiny, but the men of Possum Lodge are presented as simply hapless perpetrators of an established system. The Red Green Show is thus not meant as a tirade against masculinity. Rather, Red embodies a nostalgic version of Canadian masculinity, even as he acknowledges that it has never in reality existed. The aim of the sympathetic parody is not to exclude certain dominant conceptions of masculinity from mainstream discourse. Rather, it functions to deny them essentialist privilege. Such a denial, however, carries with it the acknowledgement that no sex- or gender-based identities have the privileged authority from which to speak. Fortunately for Scott Thompson and Rick Mercer, their characters do not wait for permission. 


\section{Conclusion:}

\section{Masculine Performance, Queer Politics, and the Erasure of Identity}

This project considers mainstream manifestations of the to-date predominantly academic argument that gender identities are fluid rather than fixed, and performative rather than essential. I have shown that sketch comedy is uniquely suited to such an analysis, especially within Canada where it is a popular cultural form. Despite Canadian sketch comedy's potent cultural commentary, however, it would be inaccurate to idealize it as a site of tremendous political acuity. I claim only that this form, with its increasing tendency to use parody to represent all genders as performative, acts as a particularly salient medium in the deconstruction of identity formation. Through my analysis of the work of Scott Thompson, Rick Mercer and Steve Smith, I have demonstrated not only that alternative conceptions of gender and sexuality are often incorporated into our mainstream culture, but that it is done through diverse and complex means. This implies a desire on the part of many Canadians to engage with non-normative constructions of gender.

In Thompson's "Buddy" monologues, the challenge to convention is achieved through camp performances of men's gay and queer identities. Mercer, meanwhile, relies predominantly on satire in his portrayal of traditional masculinity, presenting a harsher and more direct critique of conventional identity models. Smith's character Red Green, 
however, combines elements of both Mercer's and Thompson's strategies. While he is like Mercer in performing the identity of a traditional heterosexual, middle-class white man, his approach accords more with Thompson's own sympathetically camp formulation of a gay male identity.

I have focused my study on male sketch comedy, primarily because the subversive potential of hetero-masculine performativity and parody has to date been under-analyzed. Gay, queer, and feminist scholarship has tended not to consider the potential for masculinity to deconstruct itself and thus contribute to breaking down gender-based oppression. My focus has, of course, not been intended to suggest that there are no successful women working in the field. Indeed, theories of masculine performance have often been applied not only to female performers such as drag kings but also to women operating within society in general, including butch lesbians, females in traditionally male careers, and so on. Moreover, the earliest scholarly efforts to expand the analysis of camp techniques beyond a gay male community arose through discussions of feminist camp, which arguably has an equally long tradition. ${ }^{13}$

In Canada, female sketch comedians have created several notable male characters. Cathy Jones, for example, in the show This Hour Has 22 Minutes, regularly performed the indigenous character Joe Crow who, while presenting commentaries on major issues pertaining to indigenous rights in Canada, also parodied the persona of the outdoorsy Canadian male, albeit in distinctly different way than Steve Smith. Also in 22 Minutes, Mary Walsh developed the under-achieving reporter Dakey Dunn who - in contrast to Mercer's clean cut, stereotypical J.B. Dixon - wore a gold chain and polyester suit, proudly exposed his chest hair, and often offered his monologues while smoking 
cigarettes and drinking beer. Along with Mercer and Greg Thomey, Walsh and Jones also performed as the Quinlan Quints, four lazy, Newfoundland men who, by wearing identical black toques and red plaid shirts, hoped to make a fortune as Canada's next high profile quintuplets. The Quints sketch often consisted of the four scam-artists attempting unsuccessfully to convince the audience of the authenticity of their identities as male quintuplets.

Women's parodies of men's identities often present more explicit exposures of the performative quality of gender. When Walsh and Jones don manliness, they are more blatantly engaging in a political drag performance. Like Mercer, they often deliver their performances with a satirical rather than compassionate edge. Notably, the same degree of critical harshness is not brought to their performances of women's identities, which are generally gentler and more akin to camp principles. Camp performance privileges exaggeration, effeminate stylization and sympathy for its subject. This has led to a tradition of sympathetic portrayal of feminine qualities in both the gay and feminist communities.

As noted in my discussion of Thompson's material, such camp depictions give marginalized identities visibility within mainstream culture, but they also rely to some degree on essentializing clichés for their efficacy. To support a fully queer conception of sex and gender, past historical categories must all be equally destabilized. That is, all genders must be dislodged from their associations with biological sex, and be perceived and understood instead wholly as performance. But to achieve this, the conceptualization of queer performance strategies such as camp need to be expanded beyond their historical framework. By the same token, biting satires of traditional manliness may be amusing but 
they are not particularly constructive. It is often the case that the traditional heterosexual, middle-class male is depicted as having no redeeming qualities, and yet no suggestion for change is proposed; the aim of such works is more cathartic for those who feel oppressed by heterosexual men than ameliorative. The mock-macho situation comedy, meanwhile, conflates the feminist and men's rights movements, offering a gentler parody of manliness. Part of a tradition of depicting bumbling male authorities, these parodies fall short of a critique of hegemonic masculinity by encouraging viewers to be patient with its shortcomings. Despite the acknowledged inadequacy of compulsory heterosexuality, it is portrayed as a feasible and moral option.

Both the satirical and sympathetic parodies of traditional male identities encompass only a portion of contemporary performance driven interrogations of gender norms. In sketch comedy, characters such as Red Green are able to parody heteromasculine marginality by fusing camp principles with masculine performance. Currently, this form of parody, by popularizing the notion that dominant normative identities are also performative, has the greatest potential to disrupt mainstream assumptions regarding gender authenticity. While not the most radical example of critical gender performance, Steve Smith's work provides evidence that formerly hegemonic masculinities are increasingly being marginalized because of their reliance on rigid and out-dated conceptions of family, sexuality, and compulsory gender roles. Notably, at the same time, queer theory and performance has begun to acknowledge limitations to relying on constructionist theory within the realm of political activism. It is somewhat heartening to perceive characters such as Red Green exhibiting camp characteristics as a means of addressing the marginality that once dominant masculinity now sees itself occupying 
more and more often. It is increasingly evident that all sex- and gender- based identities, including those that formerly benefited from biological essentialism, have taken an interest in reformulating these identities as malleable. 


\section{Endnotes}

${ }^{1}$ The term "heteronormativity" refers to the manner in which heterosexuality is presented as ideologically universal and compulsory.

${ }^{2}$ Extensive definitions of parody can be found in Linda Hutcheon's $A$ Theory of Parody and, more recently and specific to comedy, Nicole Matthews Comic Politics Gender in Hollywood Comedy After the New Right.

${ }^{3}$ Brickell's attempt to sustain some form of a structural argument while also critiquing essentialism risks being theoretically unstable. While demanding sensitivity to sociological structures, Brickell also wants to see gender as theoretically free from natural or structural origins. For him, even if the sociological structure is grounded in false assumptions, it nevertheless has real life repercussions; but if this is the case, than the fact of their falsity appears to be moot.

${ }^{4}$ Becker limits this discussion to gays, lesbians, and heterosexuals. He does not take into consideration individuals who self-identify as bisexual, transsexual, two-spirited, or any other sexual category. Nor does he consider the attitudes of these "hip" heterosexuals toward these other identities. Indeed, scholars in general have yet to research fully the position and reception of these identity categories in relation to mainstream television.

${ }^{5}$ On the ways in which camp allows political commentary to infiltrate audiences, see Jack Babuscio and Moe Meyer. 
${ }^{6}$ Within the gay and lesbian rights movements, the essentialist discourses of identity politics were, to a certain degree, necessitated. This has been the case, for example, where claims to having "been born this way" have proven more effective in promoting mainstream acceptance than attempts to alter ideological constructions of sexuality as pursued by theorists such as Foucault and Butler. However, this non-essentialist theoretical technique has now been taken up by queer theorists and activists and it is why camp and other forms of gender performance are now considered queer, rather than exclusively gay and lesbian. Queer activists are now refuting gay and lesbian claims about their identity just like everyone else, a tension evident in queer academic ambivalence toward the legalization of gay marriage.

${ }^{7}$ In her analysis, Maltz conflates the concepts of "performativity" and "performance." Following the articulation of Butler, the term "performativity" refers to the unconscious repetition of socialized gender models. In contrast, "performance" is a conscious phenomenon. Meanwhile, the term "performative politics" is used to refer to the conscious representation of gender styles as a challenge to normative assumptions.

${ }^{8}$ While information on this topic as it pertains to Canada is sparse, recent surveys have found that Americans who watch late-night news comedies such as The Daily Show are better informed about current political events than those who do not watch late-night comedy (National Annenberg Election Survey). Furthermore, only one in four people under the age of 30 watch serious news programs. However, 60 percent of young adults now receive news about current events from shows such as The Late Show with David Letterman and The Tonight Show with Jay Leno (CBC News Disclosure). 
${ }^{9}$ While Mercer is not the only writer or producer of this work, I refer to him as the "author" of this performance because my focus in this chapter is on the visual spectacle that Mercer presents to an audience.

${ }^{10}$ According to a 1997 Maclean's article, The Red Green Show is popular not only in Canada and the United States, but also airs weekly in Australia and New Zealand.

${ }^{11}$ See Robert Hanke's analysis of the performance of masculinity in the American situation comedies Home Improvement and Coach.

${ }^{12}$ Hanke suggests that "mock-macho" comedies present homosexuality as the Other in order to reinforce hegemonic hetero-masculinity and reproduce the gender binary (13).

${ }^{13}$ For a thorough historicization and theorization of feminist camp, see Pamela Robertson's Guilty Pleasures. 


\section{Works Cited}

Babuscio, Jack. "Camp and the gay sensibility." Camp Grounds Style and Homosexuality. Ed. David Bergman (1993) 19-38.

Beauvoir, Simone de. The Second Sex (1952). New York: Vintage Books, 1989.

Becker, Ron. "Prime-Time Television in the Gay Nineties". The Television Studies Reader. Ed. Robert C. Allen and Annette Hill. New York: Routledge, 2004. 389403.

Bell, Karen. "We have lift-off." Performing Arts \& Entertainment in Canada. 31.1 (summer 1997): 46.

Berger, Maurice, Brian Wallis and Simon Watson, eds. "Introduction." Constructing Masculinities. New York: Routledge, 1995.

Bergman, Brian. "Show-no-mercy Mercer." Maclean's 111.41 (1998): 73-74.

Bergman, David. Ed. Camp Grounds Style and Homosexuality. Amherst: University of Massachusetts Press, 1993.

Bredbeck, Gregory W. "Narcissus in the Wilde." The Politics and Poetics of Camp. Ed. Moe Meyer (1994) 51-74. 
Brickell, Chris. "Masculinities, Performativity, and Subversion: A Sociological Reappraisal." Men and Masculinity 8.1 (2005): 24-43.

"Buddy Cole." The Kids in the Hall. Exec. Producer Lorne Michaels. Season 1 Volume 4. Pilot Episode, 1989.

"Buddy is Canadian." The Kids in the Hall. Exec. Producer Lorne Michaels. Season 1 Volume 3. Episode 20, 1989-1990.

"Buddy's Better." The Kids in the Hall. Exec. Producer Lorne Michaels. Season 1 Volume 1. Episode 2, 1989-1990.

"Buddy's Island." The Kids in the Hall. Exec. Producer Lorne Michaels. Season 1 Volume 3. Episode 15, 1989-1990.

Bunner, Paul. "Rick Mercer should be run out on a rail." The Report 28.2 (2001): 2.

Butler, Judith. Gender Trouble: Feminism and the Subversion of Identity. New York: Routledge, 1990.

CBC. CBC News: Disclosure. 2004. Retrieved March 13, 2006, from http://www.cbc.ca/disclosure/archives/040210_pop/stewart.html.

Coulter, Diana. "Canucks are full of yuks a Yankee blunders." Christian Science Monitor 93.144 (2001): 1.

DeMont, John. “This Hour Has 22 Minutes.” Maclean's 112.50 (1999): 76-77. 
Denisoff, Dennis. Aestheticism and Sexual Parody 1840-1940. Cambridge: Cambridge University Press, 2001.

"Doing it their Way. (Cover Story)." Maclean's 106.27 (1993): 26.

Fejes, Fred. "Advertising and the Political Economy of Lesbian/Gay Identity". Sex \& Money: Feminism and Political Economy in the Media. Ed. Eileen R. Meehan and Ellen Riordan. Minneapolis: University of Minnesota Press, 2002. 196-208.

Fiske, John and John Hartley. Reading Television. (1978) London: Methuen \& Co Ltd, 1992.

Fiske, John. "Popular Television and Commercial Culture: Beyond Political Economy." Television Studies: Textual Analysis. Eds. Gary Burns and Robert J. Thompson. New York: Praeger, 1989. 21-37.

Gatehouse, Jonathon. "Rick's Shtick." Maclean's. 117.7 (2004): 38-42.

Halberstam, Judith. Female Masculinity. Durham: Duke University Press, 1998.

Hanke, Robert. "The "mock-macho" situation comedy: Hegemonic masculinity and its reiteration." Western Journal of Communication. 62.1 (winter 1998): 74-93.

Hutcheon, Linda. A Theory of Parody: The Teachings of Twentieth-Century Art Forms. New York: Routledge, 1985. 
- As Canadian as ... Possible ... Under the Circumstances! Toronto: ECW Press \& York University, 1990.

Double Talking Essays on Verbal and Visual Ironies in Contemporary Canadian Art and Literature. Toronto: ECW Press, 1992.

"I believe in the traditional definition of family." The Rick Mercer Report. CBC, Toronto. 14 Feb. 2005.

"Improving the lives of women across Canada." The Rick Mercer Report. CBC, Toronto. 28, Feb. 2005.

Irigaray, Luce. The Sex Which Is Not One. Trans. Catherine Porter. Ithaca: Cornell University Press, 1985.

King, Thomas. "Performing 'Akimbo': Queer pride and epistemological prejudice.” In The Politics and Poetics of Camp. Ed. Moe Meyer (1994) 23-50.

Kleinhans, Chuck. "Taking Out the Trash: Camp and the politics of parody." In The Politics and Poetics of Camp. Ed. Moe Meyer (1994) 182-201.

Lang, Robert. Masculine Interests: Homoerotics in Hollywood Film. New York: Columbia University Press, 2002.

Maltz, Robin. "Real Butch: The Performance/performativity of male impersonation, drag kings, passing as male, and stone butch realness." Journal of Gender Studies. 7.3 (1998): 273-286. 
Matthews, Nicole. Comic Politics Gender in Hollywood Comedy After the New Right. Manchester: Manchester University Press, 2000.

Meyer, Moe. Ed. The Politics and Poetics of Camp. London: Routledge, 1994.

— "Under the Sign of Wild: An archeology of posing." In The Politics and Poetics of Camp. Ed. Moe Meyer (1994) 75-109.

Moore, F. Michael. Drag! Male and Female Impersonators on Stage, Screen and Television. Jefferson, N.C.: McFarland \& Company, Inc., 1994.

National Annenberg Election Survey. Daily Show viewers knowledgeable about presidential campaign. 2004. Retrieved March 13, 20006, from http://www.annenbergpublicpolicycenter.org/naes/2004 03 late-night-knowledge29-21_pr.pdf.

PBS. Red Green's Hindsight is 20/20. S\&S Productions, 2003.

Pellegrini, Ann. "Consuming Lifestyle: Community, Capitalism and Transformations in Gay Identity." Queer Globalizations: citizenship and the afterlife of colonialism. Eds. Arnaldo Cruz-Malavé and Martin F. Manalansan IV. New York: New York University Press, 2002. 134-145.

Pratt, Sam. "Big Guy." Esquire. 126.2 (Aug. 1996): 28.

"Satellite Theft: It's not like stealing candy from a baby." The Rick Mercer Report. CBC, Toronto. 21, Feb. 2005. 
Simpson, Mark. Male Impersonators. London: Cassell, 1994.

Smith, Steve and Rick Green. The Red Green Book: Wit and Wisdom of Possum Lodge Plus 100 Pages of Filler. Toronto: Macmillan Canada, 1995.

"Sometimes airlines die and go to heaven." The Rick Mercer Report. CBC, Toronto. 21, March 2005.

Thompson, Scott. Just for Laughs. CBC, Montreal. circa 1993.

Wickens, Barbara. "Handy to have Red Green along in outer space." Maclean's 110.21 (1997): 58.

Wickens, Barbara. "No rest for the wickedly funny." Maclean's 110.36 (1997): 42.

Wittig, Monique. The Straight Mind and Other Essays. Boston: Beacon Press, 1992. 